\title{
Regulation of Transcription Factors by Reactive Oxygen Species and Nitric Oxide in Vascular Physiology and Pathology
}

\author{
Stefanie Kohlgrüber, ${ }^{1}$ Aditi Upadhye, ${ }^{2}$ Nadine Dyballa-Rukes, \\ Coleen A. McNamara, and Joachim Altschmied ${ }^{1}$
}

\begin{abstract}
Significance: Cardiovascular diseases are the main cause of death worldwide and pose an immense economical burden. In most cases, the underlying problem is vascular occlusion by atherosclerotic plaques. Importantly, different cell types of the vascular wall and the immune system play crucial roles in atherosclerosis at different stages of the disease. Furthermore, atherosclerosis and conditions recognized as risk factors are characterized by a reduced availability of the vasoprotective molecule nitric oxide and an increase in reactive oxygen species, socalled oxidative stress. Transcription factors function as intracellular signal integrators and relays and thus, play a central role in cellular responses to changing conditions.

Recent Advances: Work on specific transcriptional regulators has uncovered many of their functions and the upstream pathways modulating their activity in response to reactive oxygen and nitrogen species. Here, we have reviewed for a few selected examples how this can contribute not only to protection against atherosclerosis development but also to disease progression and the occurrence of clinical manifestations, such as plaque rupture. Critical Issues: Transcription factors have pleiotropic outputs and often also divergent functions in different cell types and tissues. Thus, in light of potential severe adverse side effects, a global activation or inhibition of particular transcriptions factors does not seem a feasible therapeutic option.

Future Directions: A further in-depth characterization of the cell- and stage-specific actions and regulation of transcription factors in atherosclerosis with respect to protein-protein interactions and target genes could open up new avenues for prevention or therapeutic interventions in this vascular disease. Antioxid. Redox Signal. 26, 679-699.
\end{abstract}

Keywords: transcription factors, atherosclerosis, oxidative stress

\section{Introduction}

A CCORDING To THE World Health Organization, cardiovascular diseases (CVDs) are the major cause of death worldwide, being responsible for $\sim 30 \%$ of all fatalities (WHO fact sheet No. 317, updated January 2015). Besides the impact on human health, CVDs place an immense burden on the economy, with estimated annual direct and indirect costs of $\sim € 170$ billion already in 2006 in the European
Union (95) and currently more than US $\$ 300$ billion in the United States (130).

Heart attacks and strokes are acute events, whereas the underlying problem in the majority of the cases is an obstructed blood flow, mainly caused by atherosclerotic plaque buildup over a long time. Plaque development is initiated by recruitment and infiltration of circulating immune cells such as monocytes, into the arterial wall. In the sub-endothelial space, monocytes differentiate into macrophages that scavenge

\footnotetext{
${ }^{1}$ IUF-Leibniz Research Institute for Environmental Medicine, Düsseldorf, Germany.

${ }^{2}$ Department of Microbiology, Immunology, Cancer Biology, University of Virginia, Charlottesville, Virginia.

${ }^{3}$ Cardiovascular Division, Department of Medicine and Robert M. Berne Cardiovascular Research Center, University of VirginiaSchool of Medicine, Charlottesville, Virginia.
} 
oxidized low-density lipoprotein (oxLDL), eventually becoming lipid-laden foam cells that form fatty streaks. As disease progresses, infiltrating immune cells, buildup of dying cells, and phenotypically switched vascular smooth muscle cells (VSMC), among other mediators, contribute to formation of the atherosclerotic lesion (Fig. 1). As lesions expand, arteries become hardened and occluded (102). In late stages of the disease, plaques can become destabilized and rupture, and subsequent clot formation can lead to heart attacks and strokes.

Several diseases or disease conditions are considered as independent atherosclerotic risk factors, among them being diabetes type 2 , obesity, and metabolic syndrome, and like atherosclerosis itself, they have an inflammatory component.
All these conditions have been linked not only to oxidative stress $(55,72)$ but also to endoplasmic reticulum (ER) stress $(84,86,141)$. Furthermore, they are associated with endothelial dysfunction and senescence $(15,126,132,142,167$, 191), the prevalence of which increases with age, underscoring why atherosclerosis is an age-associated disease. Although the site of the final damage is the vessel wall, other cell types are affected and contribute to these disorders. Besides the vascular cells themselves, cells from the immune system play an integral role in such pathophysiological changes (71).

Transcription factors serve as central nodes in intracellular signaling, as they integrate multiple inputs from the environment

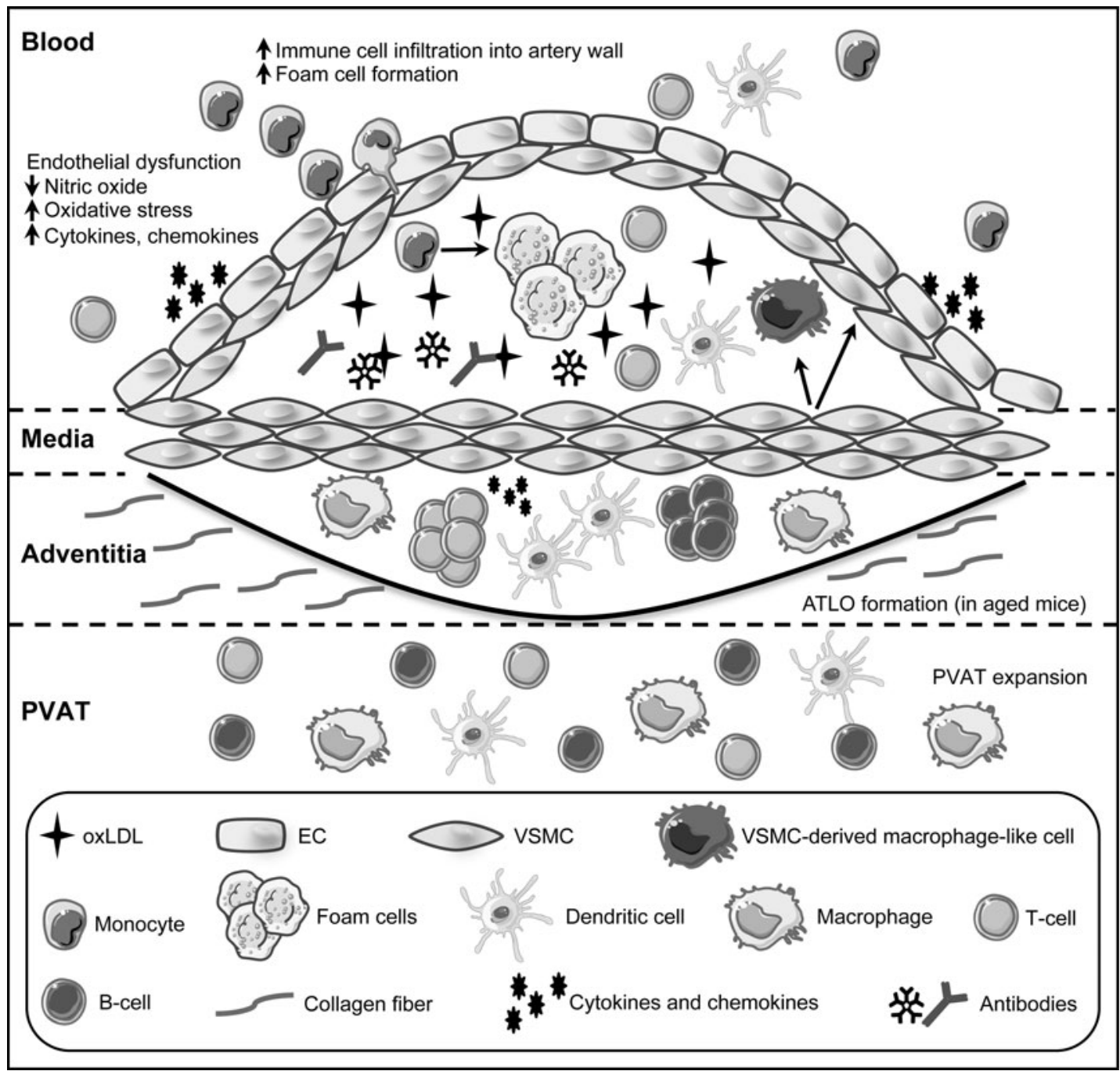

FIG. 1. Cell types and structure of the vessel wall in atherosclerosis. During atherosclerosis, buildup of oxidized lowdensity lipoprotein (oxLDL) in the arterial intima leads to endothelial cell dysfunction. The resulting inflamed endothelium secretes inflammatory cytokines, chemokines and presents adhesion molecules that recruit circulating immune cells into the artery wall. Monocytes that transmigrate into the subendothelial space take up oxLDL and differentiate into lipid-laden macrophages (foam cells). Immune components, including dendritic cells, T cells, and B cell antibodies that are specific for oxLDL, accumulate as the lesion expands, having both pro- and anti-inflammatory effects, depending on cell type. A subset of vascular smooth muscle cells (VSMC) enters a proliferative state and migrates to form the fibrous cap, whereas other SMC phenotypically switch into macrophage-like cells within lesions. Pro- and anti-inflammatory immune cell subsets are present within the adventitia and perivascular adipose tissue (PVAT) at homeostasis. These cells increase in number in response to atherogenic stimuli and organize to form arterial tertiary lymphoid organs (ATLO) with distinct B cell and T cell zones that are similar to secondary lymphoid organs in aged mice. 
and translate them into coordinated cellular responses (97). Among these external signals are reactive oxygen species (ROS) and nitric oxide (NO), key mediators of vascular functions.

Instead of discussing transcription factors that have been extensively reviewed, for example, nuclear factor kappa B (NF- $\kappa$ B) $(145,147)$ or NF-E2-related factor 2 (NRF2) (125), we will exemplarily highlight several facets of how reactive molecules regulate transcription factor functions in selected cell types and how this can promote or alleviate disease development and progression.

\section{The Vascular Wall and Immune Cells in Physiology and Pathology}

Healthy arteries consist of a monolayer of endothelial cells facing the blood flow, an adjacent medial layer of smooth muscle cells, and a surrounding collagen-rich layer, termed the adventitia. In addition, the aorta and the coronary arteries are surrounded by a layer of perivascular adipose tissue (PVAT), which is a metabolically active endocrine tissue secreting mediators that can affect the vasculature (13).

The endothelium is a key regulator of vascular homeostasis. It functions not only to transport nutrients, oxygen, and waste products to and from blood and tissue but also as an important metabolic organ, secreting autocrine and paracrine factors that result in the constriction or dilation of vessels (31, 42). Furthermore, it is a critical protective barrier separating inflammatory blood components from tissue. Importantly, factors produced by endothelial cells can be both (i) oxidizing and anti-oxidizing, (ii) vasodilatory and vasoconstricting, (iii) pro-coagulating and anti-coagulating, and (iv) proinflammatory and anti-inflammatory, depending on context and stimulus $(17,42)$. Thus, the endothelium serves an important physiological function of maintaining the balance between these opposing effects at homeostasis. In acute inflammatory conditions, endothelial cells also mediate immune cell trafficking to sites of injury or infection by upregulating adhesion molecules and cytokines, ultimately leading to extravasation and transmigration of immune cells into the tissue (Fig. 1).

NO produced by endothelial cells is a key vasodilatory factor. It regulates vascular tone and redox homeostasis, maintaining VSMCs in a quiescent non-proliferative state, and prevents immune cell recruitment to the artery wall (4). Reduced NO-bioavailability resulting in increased oxidative stress, is a hallmark of endothelial dysfunction, and it is a major contributor in the pathogenesis of atherosclerosis. It is characterized as tipping of the balance of endothelial functions toward vasoconstriction, coagulation, and inflammation. Oxidative stress can trigger endothelial cell activation, leading to a pro-inflammatory state that enhances recruitment and infiltration of circulating immune cells, such as monocytes, into the arterial wall (Fig. 1). Thus, endothelial dysfunction precedes the occurrence of visible atherosclerotic changes (31).

At homeostasis, VSMC in the media primarily serve to modulate blood vessel tone and blood pressure through contraction and relaxation. However, they are highly plastic cells that are able to alter phenotype and function in response to environmental stimuli $(7,140)$. For example, in response to vascular injury, VSMC can become capable of increased proliferation, migration, and secretion of extracellular matrix components. Furthermore, VSMC can dedifferentiate, losing their typical markers while gaining macrophage markers. Elegant studies by Owens and coworkers using lineagetracing models have shown that a significant population of lesion macrophages is derived from VSMC (58).

The role of VSMC in the pathological setting of atherosclerosis is conflicting (7). On the one hand, VSMC migration and collagen secretion leads to formation of the fibrous cap, which stabilizes the lesion. On the other hand, VSMC can also produce matrix metalloproteinases that function to erode the fibrous cap. Moreover, VSMC-derived macrophages in lesions differ from monocyte-derived macrophages and demonstrate impaired phagocytic capacity, which may hinder adequate clearance of apoptotic cells and lipids. Finally, VSMC also produce and secrete chemokines that can recruit immune cells to the lesion (Fig. 1).

Atherosclerosis also involves many components of the immune system (Fig. 1). Much like the case for endothelial cells and VSMC, it is the excessive and chronic activation of immune cells, without subsequent resolution of the immune response, that contributes to the pathogenesis of atherosclerosis. Although the role of several types of immune cells has long been recognized, it is increasingly appreciated that their functions are entirely subset- and context dependent. This does not only hold true for macrophages (26) but also for B and T cells. The B-2 cell subset is primarily pro-atherogenic, whereas B-1 cells are largely atheroprotective $(148,181)$. Similarly, $\mathrm{T}_{\mathrm{h}} 1$ and regulatory $\mathrm{T}$ cells exert opposite effects, either promoting atherosclerosis or being protective, respectively (180).

Although much focus has been given to immune cells within atherosclerotic lesions, less well known is the contribution of immune cells residing in the adventitia and PVAT (18). It has been argued that the PVAT plays a role in atherosclerosis, because it can induce inflammation in the vascular wall (186). Interestingly, the adventitia of aged mice contains arterial tertiary lymphoid organs (ATLOs), which contain distinct $\mathrm{B}$ and $\mathrm{T}$ cell zones, germinal centers, and vasculature similar to those in secondary lymphoid organs (59). Whether these ATLOs serve a protective or detrimental role in the artery wall or perhaps both is still not resolved (199).

\section{Functions of ROS and NO in the Vasculature}

In every cell of the vascular wall, a redox balance exists, which is maintained by endogenous oxidative and antioxidative systems. The oxidative systems consist of nicotinamide adenine dinucleotide phosphate (NADPH) oxidases, xanthine oxidase, and, to a minor extent, cyclooxygenase and 5-lipoxygenase (51). The major source of superoxide anions under physiological conditions is oxidative phosphorylation, since $2-5 \%$ of oxygen molecules consumed by mitochondria undergo one electron reduction (105). To cope with increased ROS, cells possess superoxide dismutases converting superoxide anions to hydrogen peroxide, which is then cleared to water and oxygen by catalase. In addition, the thioredoxin systems 1 and 2 and the glutathione system are mainly used to reduce oxidized proteins $(9,106)$.

Historically, it was assumed that ROS are only produced to destroy intruders and can damage cellular components such as DNA, lipids, and proteins. Nowadays, it is accepted that 
ROS also act as signaling molecules and second messengers (160), also in the vascular wall. In this function, they can modulate proliferation of VSMCs (27) and the endothelial transcriptome (161) without inducing damage or cell death. On the other hand, it is well described that increased levels of ROS are involved in CVDs. This so-called oxidative stress has been linked to endothelial dysfunction (17), cellular injury, and tissue damage, as well as to conditions considered as risk factors, such as diabetes (47) or obesity (55), all of which contribute to the pathology of atherosclerosis (72).

Another important second messenger in the vessel wall is NO. Originally identified as endothelial-derived relaxing factor (144), NO plays an important role for all cells of the vascular wall. It is continuously synthesized in endothelial cells by the endothelial NO synthase (eNOS) from the amino acid L-arginine and oxygen to form $\mathrm{NO}$ and L-citrulline in nanomolar concentrations (143).

$\mathrm{NO}$ is a potent powerful vasodilator and possesses various vasoprotective effects such as inhibition of platelet aggregation, suppression of adhesion of leukocytes or monocytes on the endothelial surface, inhibition of proliferation, and migration of VSMCs and vascular inflammation (104).

NO can exert its downstream effects by binding to soluble Guanylate Cyclase, promoting the formation of cyclic guanosine monophosphate (cGMP) and activating the cGMPdependent protein kinase (34). However, NO can also act as a signaling molecule through several cGMP-independent pathways, for example by affecting platelet aggregation and immune cell trafficking in the vasculature (195). Moreover, NO as well as different ROS can directly interact with cysteines and metal-containing centers of proteins to modulate the functions of those enzymes.

A reduced NO-bioavailability has been demonstrated to contribute to endothelial dysfunction in cells, animals, and humans. The molecular mechanisms leading to lower levels of $\mathrm{NO}$ in the vessel wall are widespread. Experimental evidence exists not only for a reduction of eNOS RNA amount and stability as well as diminished eNOS protein levels but also for a reaction of $\mathrm{NO}$ with superoxide anions to form peroxynitrite-all these processes, in turn, reduce NObioavailability in the vasculature $(51,80,94)$. Unfortunately, eNOS can produce not only NO but also superoxide anions when the enzyme is uncoupled. One major reason for uncoupling is the depletion of the essential cosubstrate tetrahydrobiopterin or its oxidation to dihydrobiopterin, which occurs under conditions of oxidative stress (162).

Due to their highly reactive nature, ROS and NO can interact with several proteins, such as kinases, phosphatases, and receptors, thereby modulating their functions $(46,81)$. Interestingly, given the nature of transcription factors, several amino acids described as responsible for DNA binding are modified by ROS and/or NO.

Last but not the least, oxidative stress is tightly linked to ER stress, since the latter can disturb the cellular redox homeostasis and conversely, ER malfunction can be accelerated by $\operatorname{ROS}(39,159)$. The ER is required for protein folding and maturation and nearly all proteins, which will be inserted into membranes or secreted, and, therefore, have to pass through this organelle. Associated with these functions is a stringent quality control for properly folded proteins. The oxidative environment and a specific enzymatic repertoire support the formation of disulfide bridges. This oxidative process re- quires molecular oxygen and hydrogen peroxide as electron acceptors (14).

Intuitively, reductive agents disturb the ER homeostasis; however, it has become evident that this stress response is also triggered by oxidative stress. The first adaptive reaction to reestablish homeostatic conditions is the unfolded protein response (UPR). It principally consists of three arms mediated by proteins anchored in the ER membrane and containing a luminal domain sensing critical levels of misfolded proteins $(138,158)$.

The inositol-requiring enzyme 1 has two enzymatic functions. A ribonuclease domain is activated by an intrinsic kinase and is necessary for unconventional splicing of the $\mathrm{X}$ box binding protein 1 pre-messenger RNA (mRNA), leading to production of a form of this transcription factor regulating UPR target genes.

The second arm is governed by the PRKR-like ER kinase. It phosphorylates a translation initiation factor to suppress global translation, still allowing translation of specific mRNAs. Among them is the one for activating transcription factor 4 (ATF4), which, in turn, induces the expression of several corrective genes.

The third arm is mediated by another member of the same transcription factor family, ATF6, which on ER stress translocates to the golgi apparatus, where it is cleaved to release its transcriptionally active form, again upregulating compensatory mechanisms. Importantly, sustained ER stress, which occurs on persistent oxidative stress, induces apoptosis (112).

Taken together, ROS and NO are essential for proper function of vascular wall cells. However, chronic overproduction of ROS or long-lasting reduction in NO is detrimental and will inevitably lead to death.

\section{Transcription Factors: Structure and Regulation}

Transcription factors serve as central intracellular nodes for signal integration and relay into cellular outputs at the transcriptome level. Numerous signaling cascades converge on these proteins, which themselves activate or repress a plethora of target genes. These pleiotropic responses have convincingly been illustrated through genome-wide characterization of DNA target sites of several transcription factors (89, 111, 154, 197, 212). Those studies revealed several thousand genomic binding sites for each of these proteins; further validation showed in every case the regulation of several hundred genes.

Soon after the characterization of the first transcription factors, it became evident that these proteins have a modular architecture marked by physically separable, interchangeable domains (52).

Pivotal for the function of transcription factors is their DNA binding domain, which is required for sequencespecific DNA recognition. These DNA binding domains fall into different groups, which show strong structural conservation and are used to classify transcription factors into distinct families (202). Even though DNA binding is an intrinsic property of transcription factors, some proteins lacking a DNA binding domain can also be classified as transcriptional regulators. One such family comprises the inhibitor of differentiation (Id) helix-loop-helix (HLH) proteins, which prevent DNA binding and thus, transcriptional regulation by basic HLH (bHLH) proteins $(115,137)$. 
A second crucial feature of transcription factors is the upor downregulation of transcription, mediated by activation or repression domains. These domains, which unlike the DNA binding domains barely show any structural conservation, serve to increase or decrease the recruitment of RNA polymerase to the transcription start site. This is accomplished by interaction with the basal transcription machinery or recruitment of coactivators and -repressors, respectively (53).

The activity of most transcription factors is regulated to allow cellular adaptation to internal or external signals. As transcription factor activity can be modulated by numerous mechanisms, regulatory domains of transcription factors can serve many functions (Fig. 2). One feature common to many transcription factors is dimerization (1). The formation of homo- and heterodimers within a transcription factor family or with close relatives can have several consequences. If one of the partners lacks a dimerization domain, as in case of the Id proteins $(115,137)$, this can inhibit DNA binding and thus, provide a passive mechanism precluding transcriptional regulation. Furthermore, dimerization can, depending on the dimerization partner, change DNA recognition, which results in binding to different target sequences $(66,83,113,173)$. Moreover, heteromeric complexes composed of different subunits can serve as activators or repressors of transcription, thereby altering cellular behavior $(60,109)$. Another mechanism regulating transcription factor activity, which can also be ascribed to a specific domain, is ligand binding, a feature of the majority of nuclear receptors $(12,127)$.

The different functional domains of transcription factors do not necessarily have to be arranged in a particular order, as they seem to adopt their conformation independently of each other. Furthermore, although transcription factors contain-with the exception of non-DNA binding proteins mentioned earlier-only one DNA binding domain directing them to their specific DNA target sequence, the other domains can occur in different copies and flavors within the same polypeptide.

Besides these larger domains, reversible post-translational modifications of single amino acid residues play a major role in controlling transcription factor activity (Fig. 2). They create surfaces recognized by modification-specific interaction domains (164) and thus, act as molecular switches expanding the regulatory networks controlling transcription factor activity even further.

One of the most well-characterized modification is phosphorylation, which can regulate multiple aspects of transcription factor functions, such as stability, localization, DNA binding, and protein-protein interactions (200). A few sequence-specific transcription factors can be acetylated on lysine side chains, resulting mostly in enhanced DNA binding (30). Similarly, attachment of methyl groups to the same amino acid has been described for a small number of transcription factors. However, depending on the number of methylated residues and the site of methylation, the outcomes can be greatly different (19). Addition of the small protein ubiquitin to lysine residues, ubiquitination, usually targets proteins for proteolytic degradation. Interestingly, this modification has been linked to transcriptional activation and might provide a "clock" determining how long a transcription factor can remain active. Moreover, there seem to be non-proteolytic functions of ubiquitination of transcription factors, which are mechanistically not well understood (56).

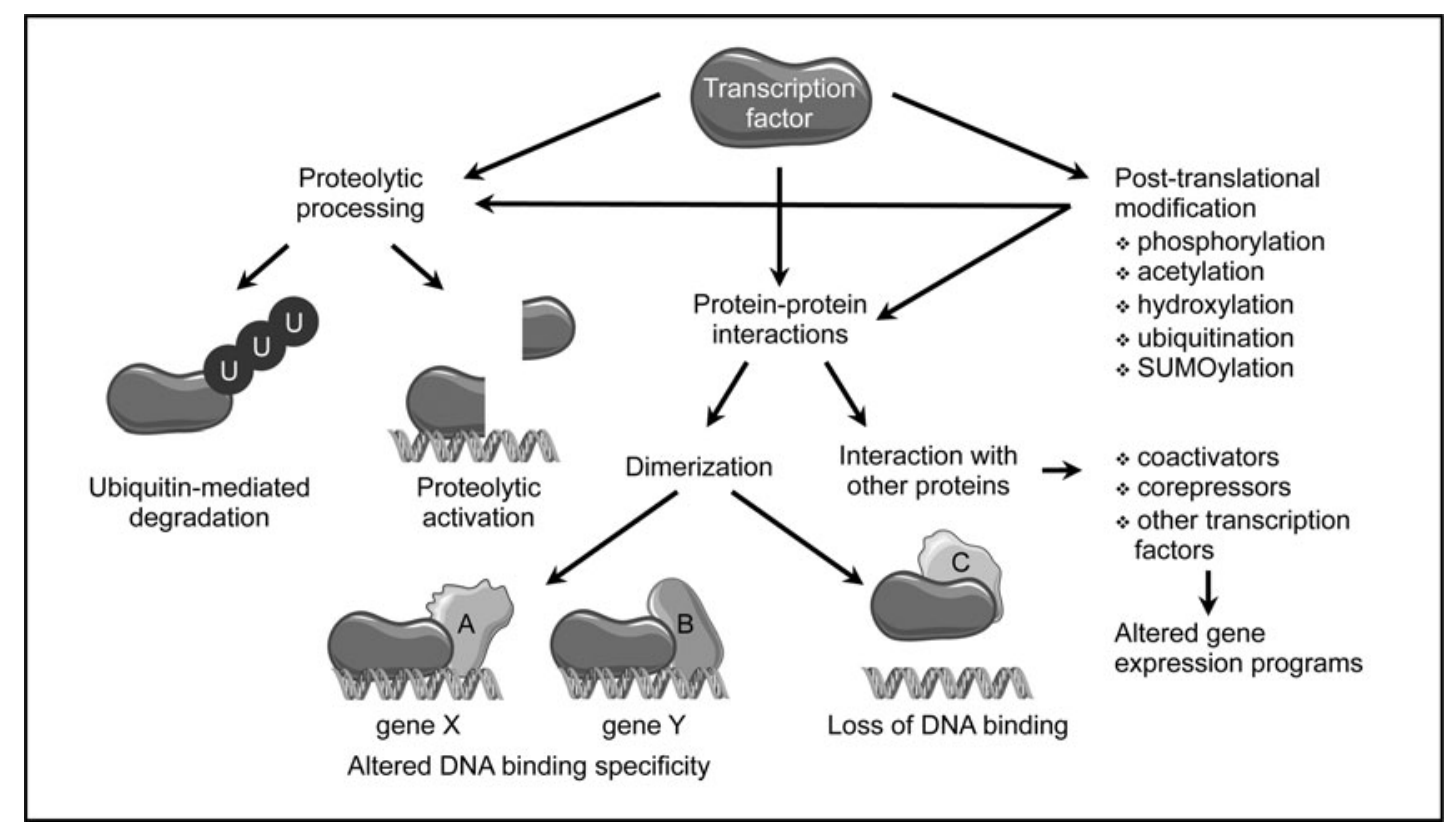

FIG. 2. Post-translational regulation of transcription factor activity. Besides regulation on the level of expression as well as RNA splicing and stability, transcription factor activity can be extensively modulated on the protein level. Ubiquitination usually leads to degradation; targeted proteolytic processing of an inactive precursor can result in activation. Dimerization with other transcriptional regulators can alter DNA binding specificity and, thus, target gene selection or even prevent binding. Furthermore, changes in interactions with other, unrelated transcription factors or coactivators and repressors can alter gene expression programs. Various covalent post-translational modifications of single amino acid residues can affect all the above-described processes. 
Attachment of small ubiquitin-like modifier (SUMO) proteins is, with a few exceptions, associated with transcriptional repression (57). Prolyl-hydroxylation affects one specific transcription factor, hypoxia inducible factor $1 \alpha$, where it is required for degradation under normoxic conditions (198). Moreover, several transcription factors can be released from membrane-bound, dormant forms by specific proteolytic cleavage, which allows translocation to the nucleus to exert their actions (82) (Fig. 2).

A direct regulation of transcription factors by the cellular redox status has been shown for members of different families. In most cases, oxidation of the sulfhydryl group of cysteine residues in the DNA binding domain leads to a reduced affinity to DNA (106). Besides these direct effects, numerous redox-sensitive signaling pathways, which are relevant for vascular diseases, can affect transcription factors (110). A few selected examples will be discussed in the following chapters.

\section{Sister-of-Mammalian Grainyhead: Two Messages from One Message}

Sister-of-Mammalian Grainyhead (SOM; also known as Grainyhead-like 3; GRHL3) is a member of a highly conserved transcription factor family. It is closely related to two other proteins, Mammalian Grainyhead (MGR or Grainyhead-like 1, GRHL1) and Brother-of-Mammalian Grainyhead (BOM or Grainyhead-like 2, GRHL2) (179, 201). All three proteins contain an N-terminal transactivation domain, a central DNA binding domain, and a C-terminal dimerization domain. Although they share similarity and recognize the same DNA-consensus motif, they are not able to functionally compensate for each other, leading to the suggestion that they regulate different sets of target genes (11). In fact, it was shown that even two isoforms of SOM activate distinct genes (65).

Several studies demonstrated that SOM plays a role in neural tube closure, wound healing, and epithelial cell migration $(16,64,78,153,178,179)$. Interestingly, SOM was independently identified in a gene trap screen for genes upregulated during apoptosis induction and then shown to be expressed in primary human endothelial cells. In addition, it was demonstrated that SOM promotes migration of these cells (63). In line with the original screen, later investigations uncovered an anti-apoptotic function of SOM (107).

Further complexity arises from the existence of humanspecific protein isoforms of SOM. Usage of an additional first exon not present in rodent genomes and alternative splicing of the primary transcript containing this exon yield a total of three SOM proteins (Fig. 3). They are identical except for their N-terminus. SOM2, the homolog of murine SOM, resembles SOM1, with the only difference being the $\mathrm{N}$ terminal 11 amino acids. The third isoform, SOM3, is derived from a transcript lacking the second exon of SOM1 and encodes an N-teminally truncated protein originally described as a putative repressor (179). All three SOM isoforms are coexpressed in human endothelial cells and are transcriptional activators $(65,107)$.

SOM1 and SOM2 are pro-migratory and anti-apoptotic in endothelial cells, whereas SOM3 has opposite effects (Fig. 3). An explanation for these different cellular outcomes

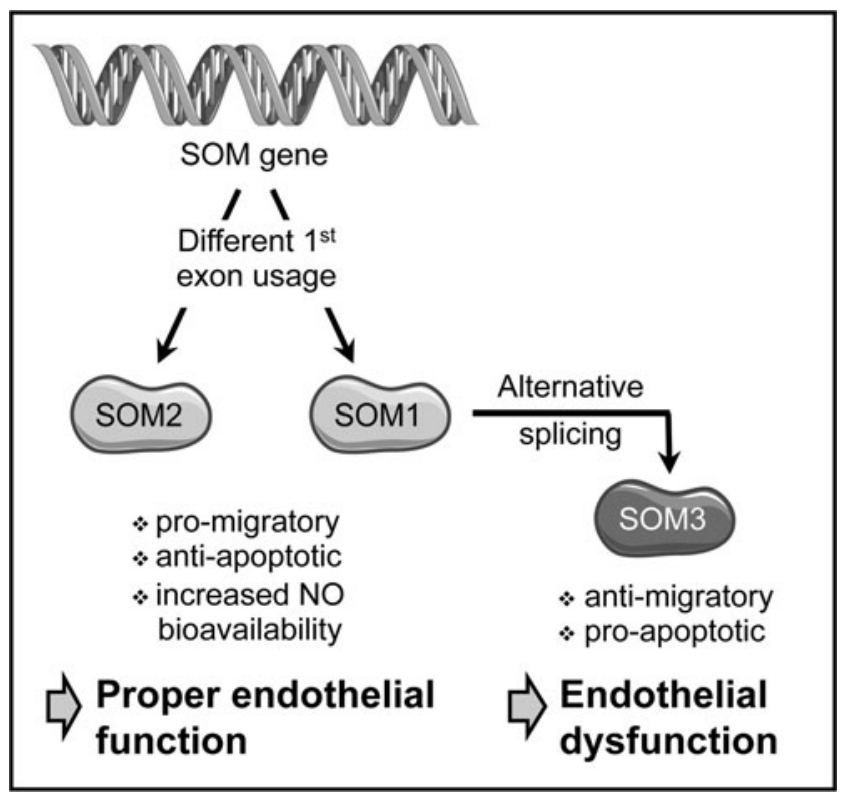

FIG. 3. Origin of human SOM isoforms. Transcriptional start at two alternative first exons results in two primary transcripts, which, with the exception of this first exon, are identical. After splicing, one transcript codes for isoform 2 of Sister-of-Mammalian Grainyhead (SOM2), which is the homolog of murine SOM. The two splice variants of the second pre-mRNA differ by the inclusion or omission of exon 2, resulting in two protein variants. The mature mRNA containing exon 2 is translated into SOM1. On the contrary, lack of exon 2 generates a small, non-productive open reading frame leading to the use of an alternate, downstream initiation codon and resulting in translation of the $\mathrm{N}$ terminally truncated isoform SOM3. Both SOM1 and SOM2 act pro-migratory and anti-apoptotic and increase NObioavailability by activating endothelial nitric oxide synthase (eNOS), thereby promoting proper endothelial function. SOM3, in contrast, induces signs of endothelial dysfunction. mRNA, messenger RNA; SOM, Sister-of-Mammalian Grainyhead.

is provided by the different target gene spectrum activated by the SOM isoforms (65). Moreover, these data suggest that the balance between the isoforms of this transcription factor could be disturbed in endothelial dysfunction.

The regulatory networks affecting SOM expression and function are only poorly understood, and it remains unclear whether the cellular redox status has an influence on this transcription factor. NO, however, plays an important role in SOM functionality in endothelial cells. It was shown that SOM induces activation of eNOS and that the pro-migratory effect of both SOM and its anti-apoptotic function are dependent on NO (107). Furthermore, SOM expression is upregulated by physiological concentrations of $\mathrm{NO}$, suggesting the existence of a positive feed-forward loop (Fig. 4).

On the molecular level, it was shown that SOM1 and SOM2 increase NO-bioavailability in endothelial cells via eNOS phosphorylation on serine 1179 by protein kinase B $\alpha /$ AKT1 $(65,107)$, resulting in increased eNOS activity (54). This is most likely due to the upregulation of protein kinase B $\beta /$ AKT2 expression, a master regulator of all AKT isoforms (150), which was demonstrated after overexpression of SOM1 (65) (Fig. 4).

Remarkably, NO not only induces an increase in SOM2 expression but also has a profound influence on the balance 


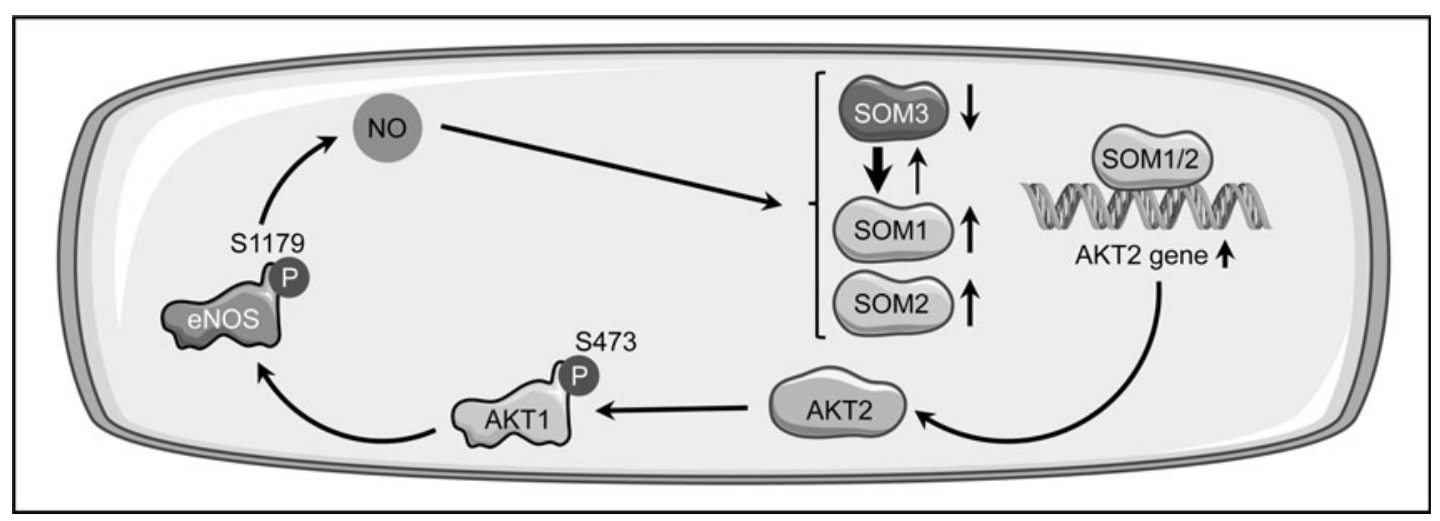

FIG. 4. Positive feed-forward loop between NO and SOM in endothelial cells. NO induces upregulation of the isoform SOM2, and, in addition tilts the balance between the alternatively spliced isoforms toward SOM1. SOM1 enhances expression of AKT2, which, in turn, leads to activation of AKT1 by phosphorylation. AKT1 activates eNOS by the same type of post-translational modification, increasing the NO-bioavailability. A similar mechanism can be inferred for SOM2, as it also positively regulates AKT1 phosphorylation.

between the two other isoforms. Treatment of endothelial cells with an NO-donor led to an elevated steady-state level of the SOM1 transcript and a concomitant decrease in the SOM3 mRNA (65) (Fig. 4). This suggests that not only transcription and post-translational modifications are regulated by stimuli affecting endothelial functions, but also RNA splicing. Interestingly, it has been described that expression of the splicing factor pre-mRNA Processing Factor 19 is downregulated in endothelial senescence, which goes along with endothelial dysfunction, and that overexpression of this protein extends the life span of endothelial cells (190). This is not an isolated phenomenon, as another splice regulatory protein, serine/arginine-rich splicing factor 1 , has been described as a marker for endothelial senescence (10).

The data presented here show an intimate involvement of SOM in endothelial function and dysfunction and, therefore, it will be of interest to better understand its regulation and target genes in disease settings and aging.

\section{Krüppel-Like Factor 2 and 4: Go with the Flow}

The family of Krüppel-like factors (KLFs), named according to their homology to the Drosophila Krüppel protein, consists of 17 members. They are characterized by $\mathrm{Cys}_{2} / \mathrm{His}_{2}$ zinc fingers in their DNA binding domain, the most abundant structural motif in transcription factors, estimated to be present in $\sim 900$ different transcriptional regulators (183). Characteristic for the KLFs are three contiguous zinc fingers at the extreme $\mathrm{C}$-terminus and additional, conserved residues between these fingers (174). In addition, three amino acids close to the histidines, which are involved in coordination of a zinc ion, and thus, critical for the three-dimensional structure, determine target site interactions (203). This results in a similar DNA recognition of G/C-rich sequences by all KLFs $(8,174)$. The variable $\mathrm{N}$-terminal part is much less conserved and contains activation as well as repression domains (8). Within the KLFs, the proteins KLF1, KLF2, and KLF4 form a closely related subgroup $(8,174)$.

A systemic knockout as well as endothelial-specific deletion of KLF2 is embryonic lethal $(96,194)$, demonstrating a requirement for this transcription factor during embryogenesis. However, hemizygous KLF2-deficiency augments diet-induced atherosclerosis on an apolipoprotein E (ApoE) negative genetic background (3), clearly indicating that KLF2 is atheroprotective. Mechanisms involved in atheroprotection by KLF2 are the upregulation of eNOS expression in the endothelium and the interference with cytokineinduced expression of adhesion molecules such as vascular cell adhesion molecule 1 (VCAM1). VCAM1 is a marker for endothelial cell activation, which occurs early in atherosclerosis development (168).

The expression of KLF2 itself is controlled by hemodynamic forces, which could explain why specific regions in the blood vessels are more prone to atherosclerotic lesion development than others, even if they are exposed to the same systemic risk factors. A steady, pulsatile blood flow is atheroprotective; however, disturbed flow in the form of oscillatory or turbulent flow creates an atheroprone environment (22). Interestingly, oscillatory shear stress also enhances ROS production by NADPH oxidases and monocyte adhesion in cultured endothelial cells (87, 88, 119). Along these lines, treatment with the antioxidant $\mathrm{N}$-acetylcysteine can abrogate the upregulation of the adhesion molecule VCAM1 by oscillatory shear stress (21). In vivo oxidative stress has been detected in atherosclerosis-susceptible regions of the mouse aorta, even in a strain with a different genetic susceptibility to atherosclerosis (68), demonstrating that oxidative stress is independent of the disease per se.

The fact that, depending on blood flow type, specific regions of the aorta are more vulnerable to atherosclerosis development than others is mirrored in the shear stress dependence of KLF2 expression. In endothelial cells, KLF2 is downregulated by atheroprone flow (73) and upregulated by laminar shear stress (168). Of note, the latter effect was much stronger when prolonged unidirectional pulsatile flow was applied instead of steady flow (33). This dependence of KLF2 expression on flow type was also shown in vivo in different regions of the rat aorta (192). Furthermore, experimental manipulation of shear stress conditions has an impact on KLF2 expression, with disturbed flow reducing KLF2 expression (207). In addition, in zebrafish mutants with a non-contractile heart and thus, no blood flow, vascular expression of KLF2 is lost (146).

On the mechanistic level, it was shown that steady laminar shear stress leads to phosphorylation of histone deacetylase 5 
(HDAC5) coupled with its nuclear export and to disruption of the interaction with myocyte enhancer factor 2C (MEF2C), which, in turn, can then activate KLF2 transcription (Fig. 5).

The relevance for HDAC5 phosphorylation was demonstrated by adenoviral overexpression of a non-phosphorylatable form, which downregulated flow-mediated KLF2 and eNOS expression and enhanced adhesion of monocytes on the endo- thelial cell surface even under laminar flow (193). Full activation of $\mathrm{MEF} 2 \mathrm{C}$ requires its phosphorylation by the extracellularsignal regulated kinase 5 (ERK5), which itself is activated by constant flow. A critical role for this phosphorylation in flowinduced KLF2 upregulation has been demonstrated by expression of a permanently active form of ERK5, which induced KLF2 expression in endothelial cells even under static

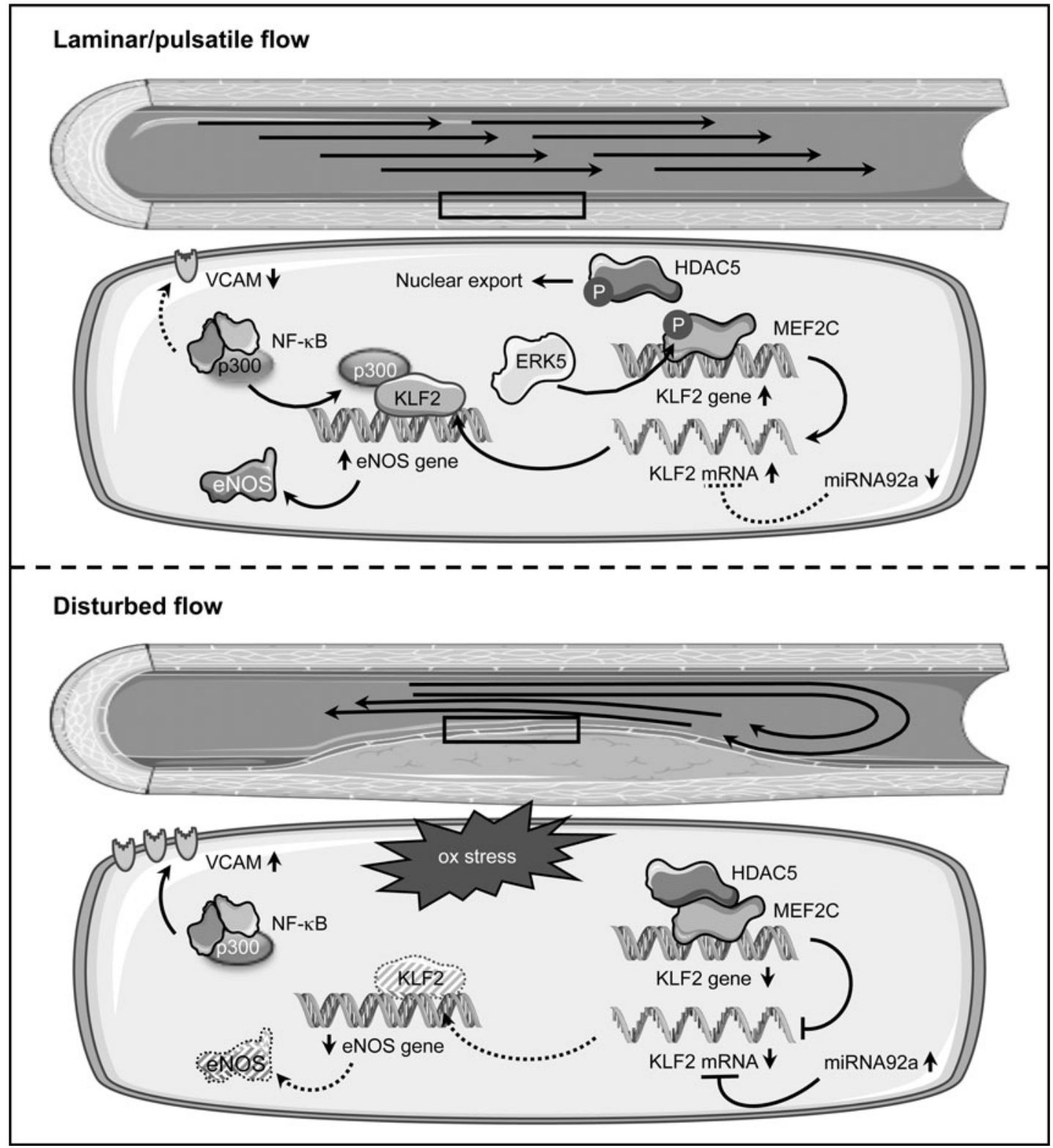

FIG. 5. KLF2 regulation and signaling in endothelial cells in response to blood flow alterations. Under laminar or pulsatile flow (upper panel), the level of Krüppel-like factor 2 (KLF2) is high due to several mechanisms. In these conditions, histone deacetylase 5 (HDAC5) is phosphorylated and exported from the nucleus. This allows transcription of the KLF2 gene by myocyte enhancer factor 2C (MEF2C), which itself is activated via phosphorylation by extracellularsignal regulated kinase 5 (ERK5). KLF2, in turn, recruits the transcriptional coactivator p300 and upregulates eNOS expression, leading to enhanced NO-bioavailability. Furthermore, sequestration of p300 compromises nuclear factor kappa B $(\mathrm{NF}-\kappa \mathrm{B})$ functions and thus, interferes with upregulation of vascular cell adhesion molecule 1 (VCAM1). Oscillatory and turbulent flow (lower panel), which are associated with oxidative stress (ox stress), interfere with high-level expression of KLF2 mediated by MEF2C, as the transcription factor itself and HDAC5 are not phosphorylated. In addition, the expression of microRNA 92a (miRNA92a) is upregulated. By binding to the $3^{\prime}$ untranslated region, this micro RNA destabilizes the KLF2 transcript. Downregulation of KLF2 entails lower eNOS expression and activation of VCAM1 transcription via NF$\kappa \mathrm{B}$ in concert with $\mathrm{p} 300$. Both the reduced NO-bioavailability and expression of adhesion molecules are characteristics of an activated endothelium. 
conditions. Conversely, a non-phoshorylatable, dominantnegative ERK5 mutant suppressed KLF2 induction by laminar flow (146). It has to be noted that ERK5 is not the kinase responsible for nuclear export of HDAC5.

In addition, laminar shear stress leads to stabilization of the KLF2 mRNA (185). One explanation for the change in the KLF2 transcript stability is microRNA-dependent degradation (Fig. 5). The microRNA 92a (miRNA92a), which, compared with KLF2, is reciprocally regulated by different flow conditions, targets the $3^{\prime}$ untranslated region of the KLF2 transcript. Expression of a miRNA92a precursor in endothelial cells reduced the levels of KLF2 and eNOS and, conversely, a knockdown increased them (204). In vivo, higher levels of miRNA92a in the atherosusceptible aortic arch of swine aortas were associated with decreased KLF2 expression, and the reciprocal situation was found in the thoracic aorta, which is much less vulnerable to plaque formation (41). Interestingly, this microRNA is upregulated not only by oscillatory flow but also by oxidative stress (25), providing a link between these two phenomena culminating on KLF2.

The upregulation of eNOS by KLF2 is simply explained by binding of the transcription factor to the eNOS gene promoter (168), whereas the suppression of the cytokine induction of adhesion molecules is based on a different mechanism. Upregulation of endothelial VCAM1 in inflammatory conditions is controlled by $\mathrm{NF}-\kappa \mathrm{B}$ both ex vivo and in vivo $(28,124,171)$. One coactivator critical for NF$\kappa \mathrm{B}$ function is p300 (170, 205). Seemingly, KLF2 sequesters this coactivator independent of its own binding to DNA, thereby compromising NF- $\kappa \mathrm{B}$ functions and upregulation of VCAM1 (168).

The closest relative of KLF2, KLF4, also has atheroprotective functions. However, the functions of these two proteins, although overlapping, are not redundant, as shown by the different phenotypes of knockout animals. Unlike KLF2-deficiency, the lack of KLF4 does not lead to embryonic lethality. Instead, the animals die postnatally due to a defective skin barrier, resulting in dehydration (165). Endothelial-specific deletion of KLF4 resulted in enhanced atherosclerosis development. Conversely, transgenic overexpression in the endothelium reduced the atherosclerotic lesion area and inflammatory cell infiltration (213).

Like KLF2, KLF4 is induced by laminar shear stress in endothelial cells. There, its overexpression induces eNOS expression and anti-thrombotic responses, for example suppression of VCAM1, whereas knockdown enhances tumor necrosis factor $\alpha$-induced expression of this adhesion molecule (70). KLF4 upregulates eNOS and suppresses the expression of VCAM1 by the same mechanisms as KLF2 (213). In addition, it is also regulated by the same upstream regulators ERK5 (139) and miRNA92a $(25,41)$.

Taken together, KLF2 and KLF4 have important atheroprotective functions in the endothelium by enhancing NOproduction via the upregulation of eNOS and interfering with the expression of surface molecules that are critical for monocyte adhesion. Furthermore, they are co-regulated by the same pathways. These two closely related transcription factors cannot fully compensate for each other as demonstrated by the different phenotypes of the knockout mice. Nevertheless, they seem to have not only overlapping and partially redundant but also distinct functions in the endothelium (69), which have to be dissected further in the future.

\section{Id3: Guilty by Association}

The four Id proteins (Id1-4) interfere with the class I bHLH transcription factors, known as E proteins. E proteins contain an HLH domain, which facilitates dimerization with other bHLH proteins, and a basic DNA binding domain. Id proteins lack the latter, but retain the capacity to dimerize with $\mathrm{E}$ proteins via the $\mathrm{HLH}$ region, resulting in $\mathrm{E}$ protein sequestration and inhibition. This dominant negative effect of Id proteins can, depending on the E protein bound, lead to activation or suppression of gene transcription. All Id proteins have been implicated in growth control, which is most likely exerted through the suppression of cyclin-dependent kinase inhibitor (CDKI) expression $(157,211)$.

One of the Id proteins, Id3, is implicated in different aspects of vascular pathologies (49). It has been shown that ROS can directly induce proliferation of VSMC (152), which is also promoted by angiotensin II (Ang II), an inducer of oxidative stress in the vasculature. The Ang II effect is more pronounced in neointimal VSMC than in medial cells or the normal vessel wall (29). Interestingly, Id3 is upregulated by Ang II in VSMC in a superoxide-dependent manner. Furthermore, it has been shown that Id 3 represses expression of p21 and p27, two members of the CDKI family, after Ang II treatment $(131,136)$, placing it in a central position in redoxsensitive growth control of VSMC. Along these lines, Id3 is profoundly upregulated in neointimal VSMC in vivo after wire injury of the carotids (136) and strongly expressed in human atherosclerotic plaques, but not in normal coronary arteries (196).

A splice variant of human Id3 has been identified, which possesses a unique $\mathrm{C}$-terminus of 60 amino acids generated by read-through into a coding intron. This isoform, Id3 L, seems to have impaired dimerization capacity toward Eproteins (32). A similar intron inclusion can occur in rats, leading to an mRNA coding for Id3a, which also has a unique C-terminus, in this case of 29 amino acids (117). Both isoforms are coexpressed in cultured VSMC; however, the expression of fully spliced Id 3 is much higher. A change was noticed after denudation of the carotid artery, when the Id3a RNA, which was undetectable in uninjured carotid arteries, was upregulated beginning 6 days after injury. Expression was detected mainly in the growing neointima and inner media and was sustained for the whole observation period of 28 days. During this time window, no Id3 transcript was observed (Fig. 6). Upregulation of the alternative isoform is not unique to the animal model, as the corresponding $\mathrm{Id} 3 \mathrm{~L}$ transcript was also detectable in human carotid atherosclerotic plaques (117).

A similar switch in Id3 isoforms was also observed on the protein level. Although Id 3 levels increased in carotid arteries up to 7 days after balloon denudation before they returned to baseline levels, Id3a protein accumulated later, but upregulation was sustained (50).

The functional outputs of the two Id3 isoforms in VSMCs are strikingly different. Overexpression of Id3 induced proliferation, whereas Id3a decreased the number of viable cells by apoptosis induction (Fig. 6). Adenoviral expression of Id3a immediately after balloon injury reduced neointima formation in vivo. Furthermore, Id3, in contrast to Id3a, inhibited transcription of the cell cycle inhibitor p21 $(50,117)$. This was corroborated by the reduced proliferative capacity 


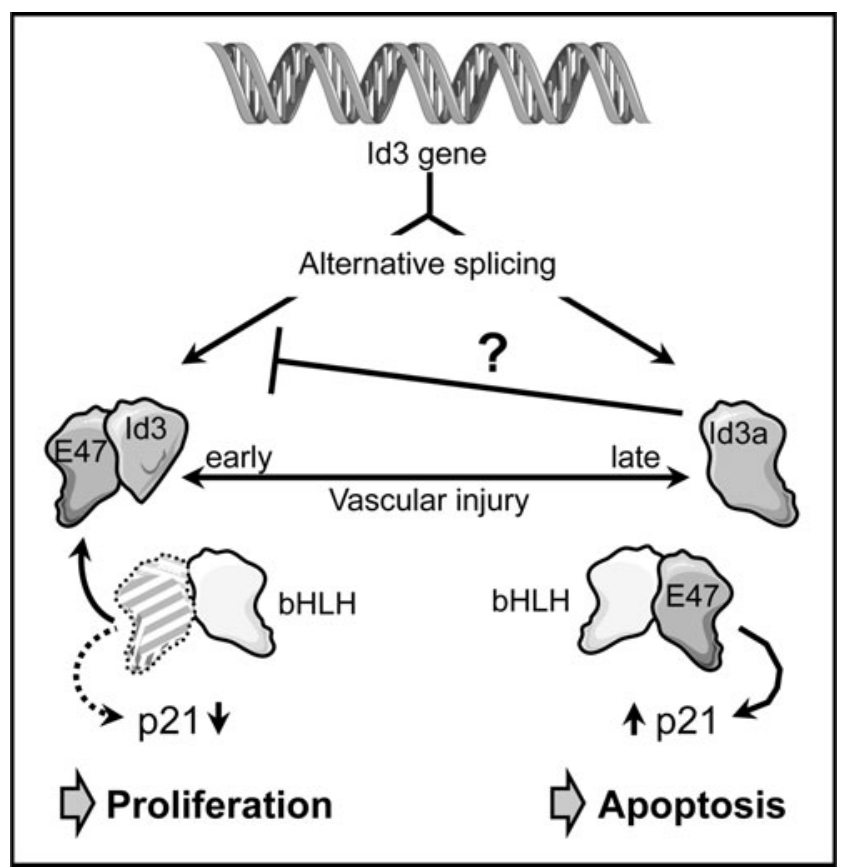

FIG. 6. Id3 regulation of VSMC proliferation and apoptosis. The inhibitor of differentiation 3 (Id3) pre-mRNA can be alternatively spliced. In one splice variant, a coding intron is retained, leading to expression of a larger protein, Id3a, with a unique $\mathrm{C}$-terminus and lower affinity to the basic helix-loop-helix (bHLH) protein E47. Id3 is upregulated in VSMCs early after vascular injury. Sequestration of the ubiquitous bHLH protein E47 by Id3 prevents upregulation of the cell cycle inhibitor p21 by a heterodimer of E47 with another bHLH protein, resulting in increased VSMC proliferation and neointima thickening. Later after injury, the balance between the two Id3 forms shifts toward Id3a, which suppresses the production of Id3 by an unknown mechanism. As a further consequence, E47 becomes available for dimerization with other bHLH proteins and thus, upregulation of $\mathrm{p} 21$, which can lead to the induction of apoptosis, possibly contributing to plaque instability.

of VSMC from Id3 knockout mice and their inability to suppress transcription from the p21 promoter (50).

Inline with the notion that dimerization of human $\operatorname{Id} 3 \mathrm{~L}$ with ubiquitous bHLH proteins is impaired (32), Id3a cannot interfere with E47-mediated transcriptional upregulation of p21 (50), which might, in turn, induce apoptosis (118). One of the most interesting points in this study was the observation that Id3a can downregulate Id3, suggesting that upregulation of Id3a establishes a feedback loop controlling a switch in VSMC phenotype (Fig. 6). Which signals initiate the switch in Id3 pre-mRNA splicing is currently not known.

Taking this evidence together, it is likely that the switch in Id3 pre-mRNA splicing induces a transition from VSMC proliferation toward apoptosis. This change also occurs in atherosclerotic plaques, where advanced lesions are characterized by a low proliferative index and increased apoptosis of VSMC finally leading to plaque rupture (5).

Besides these roles in VSMC proliferation and apoptosis, Id 3 has been shown to mediate protection against atherosclerosis in vivo. This was demonstrated by an increase in atherosclerotic plaques in ApoE/Id3-double knockout mice fed a Western diet exhibiting increased atherosclerosis compared with ApoE-deficient/Id3-proficient animals. This protective role of Id3 was also demonstrated in LDL receptor (LDLR)/Id3 double knockout mice. In both LDLR and ApoE knockout mouse models, Id3-deficiency led to decreased numbers of aortic B cells (103). B cells can localize to atheroprone regions, and $\mathrm{Id} 3$ mediates $\mathrm{B}$ cell homing to the aorta by upregulating the expression of the chemokine (C-C motif) receptor 6 (CCR6). CCR6 has been implicated in homing to sites of disease, and its expression is downregulated by the bHLH protein E12, which is antagonized in the presence of Id3 (38) (Fig. 7).

Another consequence of Id3-defciency was an increased macrophage burden in the plaque areas, most likely mediated by an increase in VCAM1 expression in VSMC, again due to insufficient interference with E proteins (103) (Fig. 7). Although endothelial VCAM1 is required for initial monocyte recruitment, its expression on VSMCs in the developing plaque might be necessary for macrophage retention.

Furthermore, B cells, primarily the B 1a subtype, produce IgM-type antibodies against oxLDL that can block oxLDL uptake by macrophages, thereby inhibiting foam cell formation $(93,169)$ (Fig. 7). Therefore, the reduced aortic B cell homing in Id3-deficient mice may also contribute to increased macrophage numbers in lesions (38). These data illustrate that Id 3 is critical for B cell-mediated protection in early stages of atherosclerosis development.

Interestingly, a non-synonymous single-nucleotide polymorphism (SNP) in Id3 has been associated with subclinical atherosclerosis in humans $(37,114)$. This SNP, which does not affect expression, leads to an amino acid exchange in the C-terminus of Id3, which is essential for dimerization with bHLH proteins (23). The mutant protein has reduced affinity to E proteins, resulting in impaired interference with transcriptional activation by these bHLH transcription factors (37). Together with the mouse experiments, this supports a role for Id3 in atheroprotection, mediated in large parts via regulating macrophage and immune cell content in the plaque, which, in the long run, might open up avenues for immune system-directed therapeutic approaches.

\section{ATF6: When Stress Kills}

The seven activating transcription factors (ATF1-7) belong to one of the largest classes of transcriptional regulators, the basic leucine zipper proteins identified nearly 30 years ago (67). The members of this superfamily can form homoand heterodimers within specific subfamilies (66). They are characterized by a contiguous bipartite $\alpha$-helical stretch encompassing a DNA binding domain and a dimerization region termed leucine zipper, the latter forming an amphipatic helix characterized by a periodic repetition of leucine residues. The leucine zippers of dimerization partners are arranged as a coiled coil of two parallel helices positioning the DNA binding domains such that the dimers form a "scissorsgrip"-like structure (189). The ATFs are closely related to Cyclic AMP Response Element Binding Proteins (188).

ATF6 is unique among the ATF transcription factors, as it is synthesized as a $90 \mathrm{kDa}$ transmembrane protein that is inserted into the ER membrane. Induction of ER stress leads to appearance of a $50 \mathrm{kDa}$ proteolytic cleavage product that is localized in the nucleus (76). Processing encompasses 


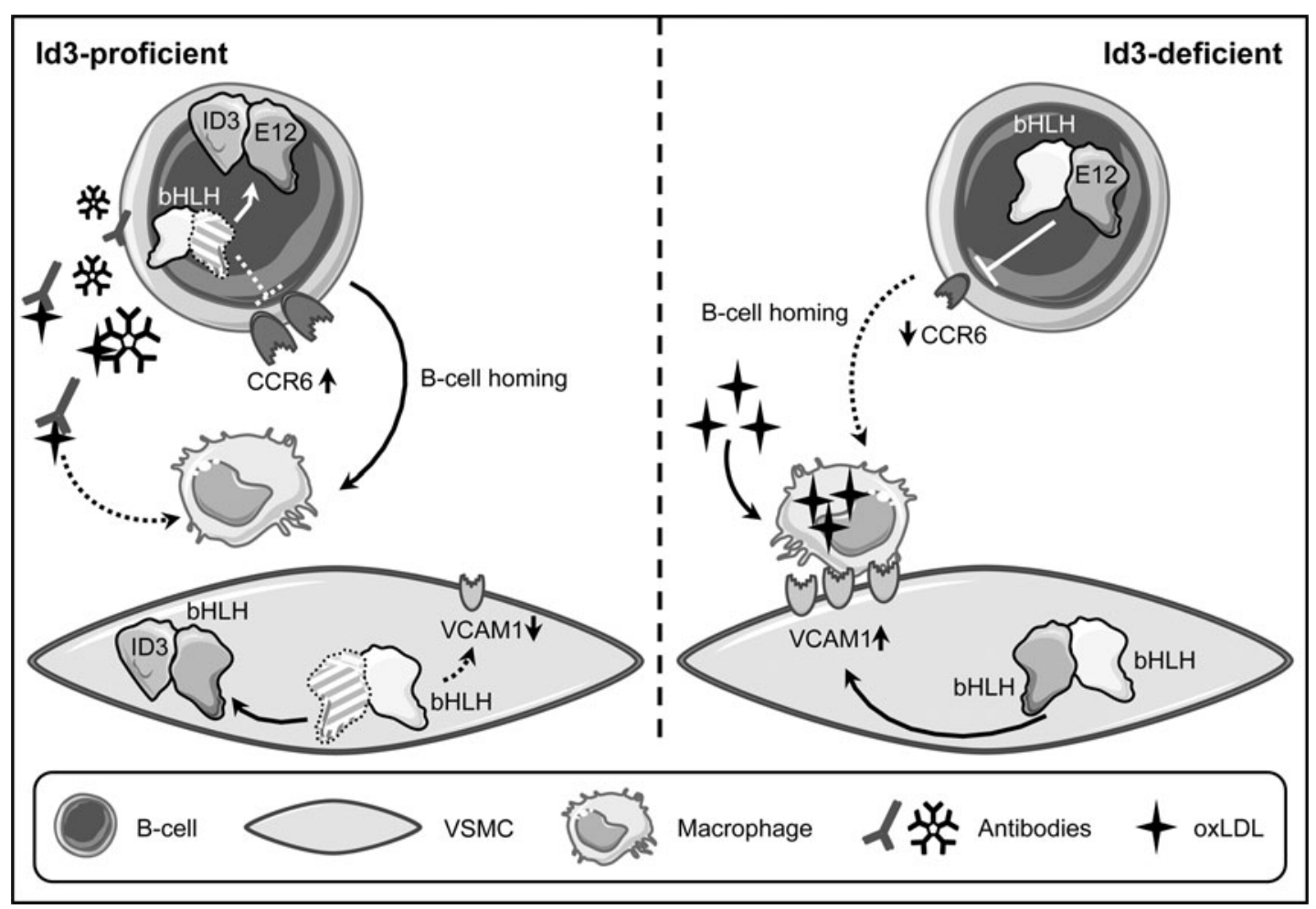

FIG. 7. Mechanisms of atheroprotection by Id3. Id3-deficiency leads to enhanced atherosclerosis development in different atheroprone mouse models. In Id3-proficient animals, Id3 can induce upregulation of the cell surface receptor chemokine (C-C motif) receptor 6 (CCR6) in B cells. Mechanistically, this is due to sequestration of the ubiquitous bHLH protein E12, which can suppress CCR6 expression. Consequently, B cell homing to sites of disease is impaired, when Id3 is missing. In addition, as Id3 can suppress VACM1 expression in VSMCs, again through sequestration of another bHLH transcription factor, it can prevent adhesion of macrophages. In Id3-deficient animals, the upregulation of VCAM1 in these cells leads to macrophage retention and together with the diminished B cell homing, this could explain the increase of plaque macrophage content. Furthermore, the B cells secrete IgM antibodies scavenging oxLDL. When, due to Id3deficiency, the homing of B cells is impaired, oxLDL can be taken up by macrophages.

reduction of disulfide bridges linking the luminal domains of individual ATF6 molecules, thereby creating monomers. Only these monomers are transported to the golgi apparatus, where they are sequentially cleaved by two enzymes, site-1and site-2-protease, leading to the release of the transcriptionally active $50 \mathrm{kDa}$ form, which is imported into the nucleus (134).

The induction of ER stress provides a compensatory, atheroprotective mechanism. However, in pathological settings such as atherosclerosis, sustained activation of this pathway can promote cell death (163). Endothelial cell apoptosis is an early event in atherosclerosis development, whereas death of VSMCs (6) and especially foam cells (77, 214) seems to occur only in advanced stages of disease and contributes to plaque instability and the risk for rupture. An involvement of ER stress in plaque morphology and stability was suggested by the observation that an increase in ER stress markers was observed in VSMC and foam cells from thin-cap atheromas and ruptured plaques of human atherectomy specimens, but not in the fibrous caps of thickcap atheromas (133).

A mechanistic link between ER stress and macrophage apoptosis was provided by the fact that 4-phenylbutyrate (PBA) can reduce lipid-induced ER stress as well as apoptosis in macrophages. Furthermore, treatment of ApoE- deficient mice with PBA during the last 2 weeks of an 8-week period on Western diet reduced atherosclerosis and the percentage of apoptotic cells in the lesion area (40). Interestingly, ER stress is involved in oxLDL-induced lipid accumulation in macrophages through upregulation of the scavenger receptor CD36 (208) (Fig. 8), one of the two principal receptors responsible for oxLDL uptake (92). In advanced atherosclerotic lesions, where apoptosis of foam cells is observed, these cells show-consistent with early studies demonstrating increased levels of free cholesterol in advanced plaques (108) — an accumulation of free cholesterol (176). This increase in free cholesterol content is linked to the $\mathrm{ER}$, as this organelle is the site of cholesterol toxicity in these cells (44). In addition, cholesterol-induced macrophage apoptosis requires ER stress pathways (35).

ATF6 has been implicated in multiple aspects of foam cell differentiation and apoptosis. An involvement of ATF6 in ER stress induction in macrophages treated with oxLDL was demonstrated by the upregulation of its proteolytically activated form. Furthermore, downregulation of ATF6 by RNA interference reduced cholesterol accumulation, most likely due to impaired upregulation of CD36, and attenuated apoptosis $(208,210)$. Conversely, CD36 silencing interfered with nuclear translocation of ATF6 (208). These findings are indicative of a feed-forward loop with CD36-mediated oxLDL 


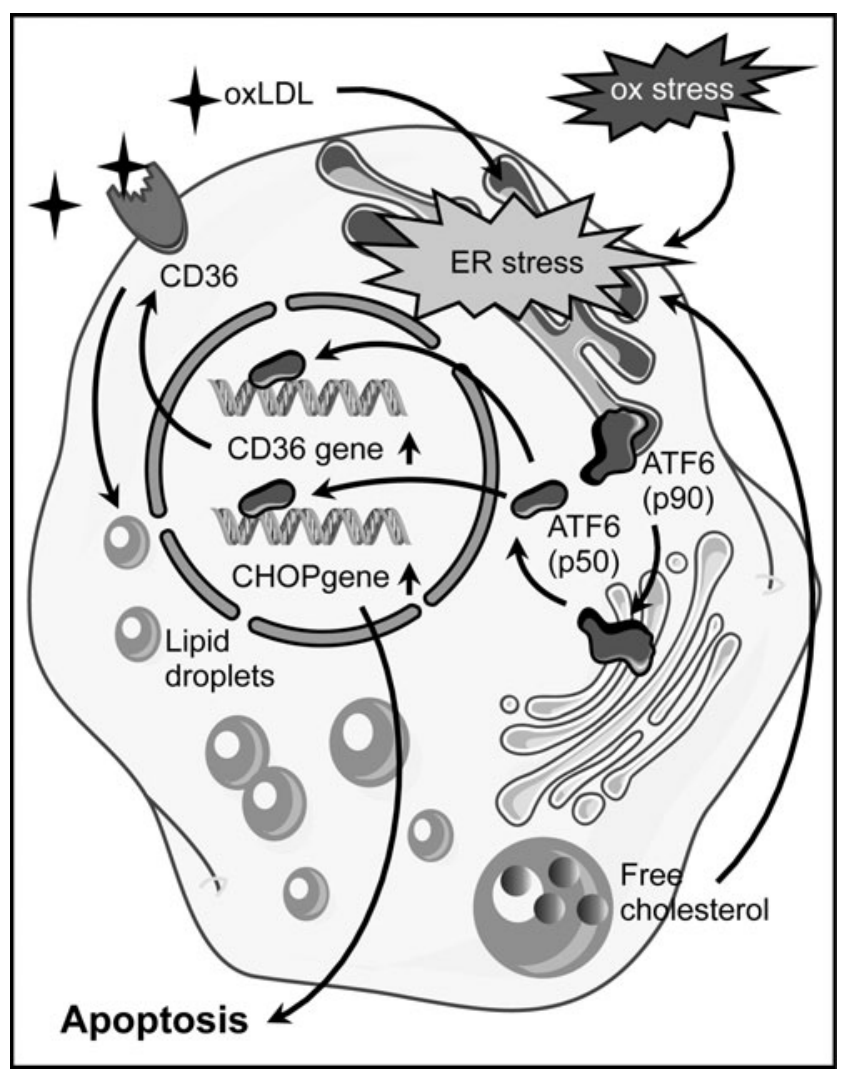

FIG. 8. Apoptosis induction by ATF6 in foam cells. Oxidative stress (ox stress) and oxLDL induce endoplasmic reticulum (ER) stress in foam cells. One consequence is the transport of the membrane-bound $90 \mathrm{kDa}$ precursor of activating transcription factor 6 (ATF6 (p90)) from the ER to the golgi apparatus. There, it is proteolytically cleaved and the $50 \mathrm{kDa}$ ATF6 (ATF6 (p50)) protein is released. After its nuclear import ATF6 (p50) upregulates transcription of the scavenger receptor CD36. The increase in CD36 enhances oxLDL uptake and accumulation of free cholesterol in lipid droplets, which, in turn, further promotes ER stress. Upon sustained ER stress, ATF6 induces apoptosis by upregulating expression of the pro-apoptotic protein CCAAT/ enhancer-binding protein homologous protein (CHOP).

uptake triggering the ER stress response, which, in turn, is required for CD36 upregulation (Fig. 8). CD36 plays an essential role in atherosclerosis, as CD36-deficiency results in reduced atherosclerotic lesion size, and it was speculated that macrophages are the cells that are critical for this effect (43, 91). Interestingly, macrophages from CD36 knockout mice showed reduced intracellular ROS generation on oxLDL stimulation (91).

Another downstream effector of ATF6 in ER stress is the pro-apoptotic CCAAT/enhancer-binding protein homologous protein (CHOP). The levels of $\mathrm{CHOP}$ in macrophages increase in response to oxLDL, and this upregulation is abrogated by downregulation of ATF6 (210) (Fig. 8). In vivo, CHOP contributes to plaque instability and plays a crucial role in cholesterol accumulation in the ER of macrophages and their apoptotic death (182). Furthermore, CHOPdeficient mouse models for atherosclerosis are characterized by a reduction in the size of aortic root lesions and necrotic areas. In addition, they show a decrease in macrophage ap- optosis in the lesions (177). This pathway seems to be also activated in humans, as macrophages in instable or ruptured plaques are characterized by increased $\mathrm{CHOP}$ expression and the CHOP-positive cells show DNA strand breakage that is indicative of apoptosis (133).

A direct link between oxidative stress and the activation of ATF6 has been demonstrated ex vivo in a cell line, where it was shown that ROS upregulate site-2 protease (62). Furthermore, the flavonoid quercetin, which has anti-oxidative properties, inhibits the oxLDL-triggered nuclear translocation of ATF6 in macrophages. This is associated with reduced expression of CHOP and attenuation of oxLDL-induced apoptosis (209).

The cumulative evidence indicates that oxidative stress and the ER stress response with ATF6 as one of its effector arms are involved in lipid overloading of macrophages, foam cell apoptosis, and plaque destabilization and could thus be of relevance in the treatment of advanced atherosclerosis.

\section{Estrogen Receptors: Who Does the Job in Atheroprotection?}

In women, clinical manifestations of atherosclerosis occur approximately a decade later than in men. These gender differences are apparent not only in clinical presentation but, also in subclinical structural changes in the different vascular beds, as well as in plaque morphology $(116,120)$. Although the progression rate of age-related arterial dysfunction at younger age is higher in men, menopause demarcates a point of turnaround. There is a roughly tenfold increase in the onset of CVD - the major manifestation of atherosclerosis-in postmenopausal women, whereas the increase in men of the same age group is only about half of that (98). This menopausal transition in cardiovascular risk points toward a critical role for the primary female sex hormone estrogen in cardiovascular protection and indeed, it has been shown more than 60 years ago that estrogens can inhibit atherosclerosis (149).

Originally, estrogen actions had been attributed to proteins belonging to the superfamily of nuclear receptors (155), namely the estrogen receptors $\alpha$ and $\beta(\mathrm{ER} \alpha$ and $\mathrm{ER} \beta)$. After a ligand-induced conformational change, dimers of these receptors either act as sequence-specific transcription factors or modulate the activity of other transcription factors without binding to DNA. However, a fraction of these classical ERs is present in a larger complex outside the nucleus, which induces signal transduction events through various downstream kinases, leading to transcriptional and non-transcriptional outputs (99). Moreover, estrogen does not only act through nuclear receptor type sensor proteins but also induces very rapid responses via the G-protein-coupled estrogen receptor 1 (GPER1) (151).

It has been shown that systemic administration of $17 \beta$ estradiol reduces the inflammatory response (123), leukocyte infiltration (206), and neointimal proliferation (24) after vascular injury. These observations suggest that more than one cell type in the vascular wall is affected by estrogen. All three receptors, $\mathrm{ER} \alpha, \mathrm{ER} \beta$, and GPER1, are expressed in endothelial cells and VSMCs (90), but the data as to which type of receptor is involved in atheroprotection are conflicting. $\mathrm{ER} \alpha$ has been described as the major mediator of the atheroprotective effects of $17 \beta$-estradiol in ApoE-deficient mice (79), whereas 
estrogen can attenuate early atherosclerotic lesion development even in ER $\alpha$-deficient, ovariectomized animals (187). Furthermore, there is evidence that GPER1 protects against atherosclerosis (122).

On the mechanistic level, estrogen supports endothelial NO-production by activating eNOS (Fig. 9). An involvement of a membrane-associated receptor was suggested by the observation that a membrane-impermeable estrogen conjugate can rapidly activate eNOS (75). Later on, it was demonstrated that an N-terminally truncated variant of $\mathrm{ER} \alpha$, $\mathrm{ER} \alpha 46$ is responsible for this effect, while at the same time it inhibited transcriptional activation by full-length $\mathrm{ER} \alpha(45$, 100). This activation of eNOS requires the tyrosine kinase cSrc at the cell membrane (74), which upon estrogen treatment becomes phosphorylated on tyrosine 419 . It then phosphorylates ER $\alpha 46$, favoring the assembly of a complex containing cSrc, ER $\alpha 46$, and PI3-kinase, which results in the successive activation of Akt1 and eNOS $(74,101)$. Interestingly, treatment of endothelial cells with specific GPER1 agonists and antagonists also demonstrated an influence of this receptor on eNOS activation, again via the PI3-kinase pathway (122) (Fig. 9).

Besides activating eNOS, estrogen suppresses monocyte adhesion to endothelial cells $(128,172)$; however, the de- tailed pathways are less well described. On one hand, this is achieved by suppressing the upregulation of adhesion molecules such as VCAM1 by interfering with NF- $\kappa$ B activation through stabilization of its inhibitor $\mathrm{I} \kappa \mathrm{B} \alpha$ (172) (Fig. 9). Again, it is debatable as to which ER mediates this effect, as it has been shown that a selective GPER 1 agonist can attenuate the upregulation of VCAM1 (20). In addition to its effects on gene expression, $17 \beta$-estradiol can inhibit leukocyte adhesion by blocking secretion of monocyte chemoattractant protein-1 and interleukin 8 without affecting their expression (156) (Fig. 9).

With respect to neointima formation, it has been shown that ovariectomy induces aortic intimal thickening, which is abrogated by $17 \beta$-estradiol by preventing basic fibroblast growth factor accumulation, thereby inhibiting the mitogenic response of VSMC to this pro-atherogenic factor $(166,175)$. Later on, it was shown that inhibition of VSMC proliferation and migration is due to non-nuclear estrogen receptor signaling involving $E R \alpha$ and protein phosphatase 2A (184). Interestingly, a recent study indicated that GPER1 also plays a critical role in maintaining the differentiated phenotype of VSMC and suppression of their migration by activating the ERK1/2 pathway (85).

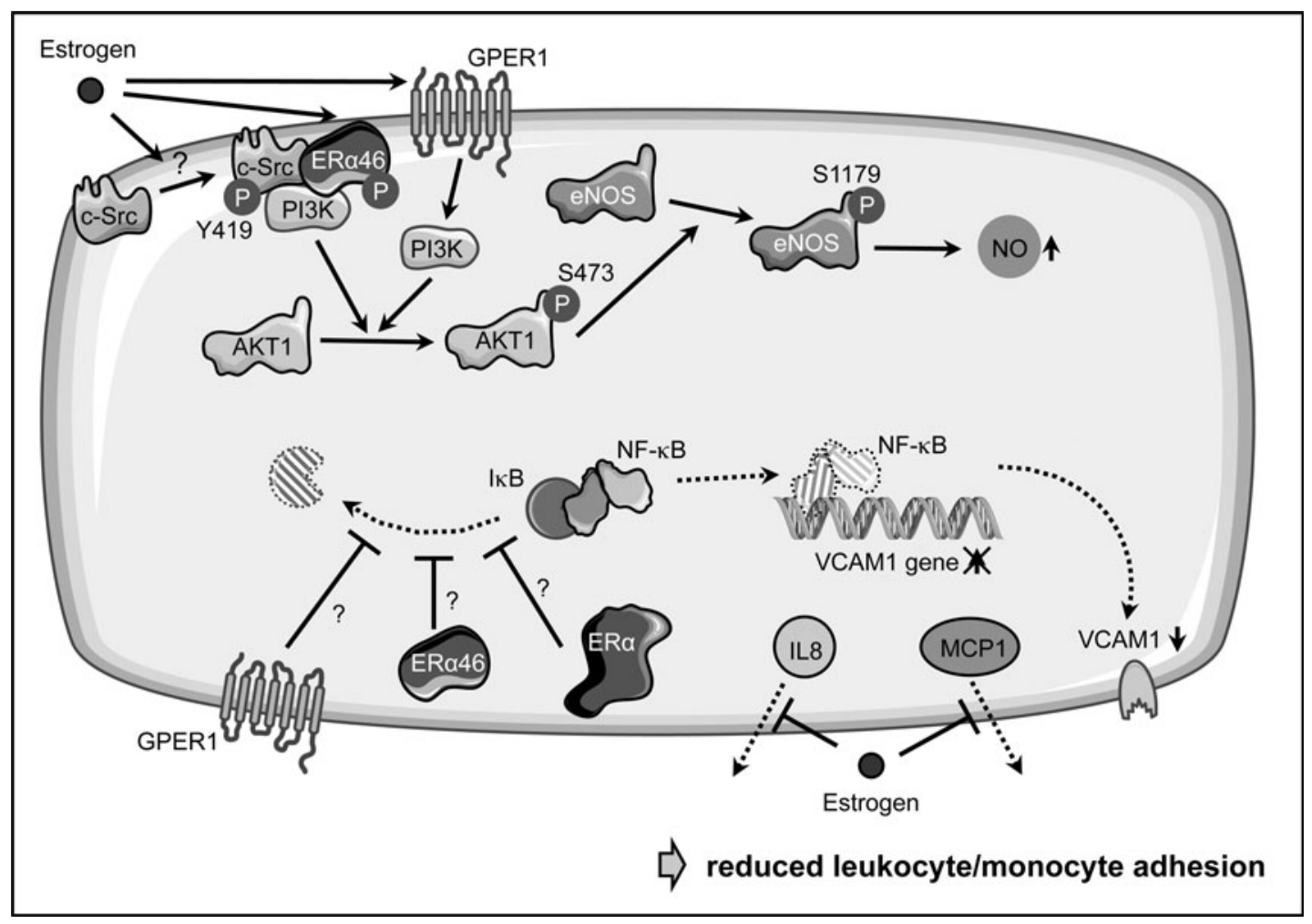

FIG. 9. Atheroprotective estrogen actions in endothelial cells. Estrogen can prevent endothelial dysfunction in multiple ways. On one hand, it induces phosphorylation of membrane-bound s-Src on tyrosine 419, which then phosphorylates a $46 \mathrm{kDa}$ variant of estrogen receptor $\alpha(\mathrm{ER} \alpha 46)$, favoring the assembly of a complex containing c-Src, ER $\alpha 46$, and PI3-kinase (PI3K). The latter can phopshorylate AKT1, which, in turn, activates eNOS by phosphorylation on serine 1179 , leading to increased NO-production. However, also the G-protein-coupled estrogen receptor 1 (GPER1) was shown to increase eNOS phosphorylation in a PI3K-dependent manner. Furthermore, estrogen can reduce the NF- $\kappa \mathrm{B}$-dependent upregulation of VCAM1 by interfering with the degradation of its inhibitor nuclear factor kappa B inhibitor a $(\mathrm{I} \kappa \mathrm{B} \alpha)$ and thus, nuclear translocation of $\mathrm{NF}-\kappa \mathrm{B}$. However, it is currently not known as to which estrogen receptor is responsible for this effect and how it is mediated. Finally, estrogen blocks the secretion of interleukin 8 (IL8) and monocyte chemoattractant protein-1 (MCP1) without affecting their expression; this, together with the diminished VCAM1 expression, prevents adhesion of leukocytes and monocytes. 
In addition to its impact on endothelial and smooth muscle cells, estrogen can reduce oxidative stress in the vasculature by regulating various ROS-producing and -removing enzymes (2). However, mechanistic insights into which estrogen receptors are involved are currently missing.

The complex network of estrogen receptors and actions indicates that simple hormone replacement therapies should be taken with caution. Along these lines, the American Heart Association has advised in 2011 that hormone therapy and selective estrogen receptor modulators should not be used for primary or secondary prevention of CVD in postmenopausal women (129).

A further delineation of the exact pathways contributing to the atheroprotective effects of estrogen and the use of receptor-specific agonists and antagonists $(90,121)$ affecting non-genomic responses as well as the timing of their delivery (61) might in the future help to develop new therapeutic approaches toward reducing the cardiovascular risk in postmenopausal women.

\section{Conclusions/Future Directions}

The examples discussed earlier illustrate how transcription factors are involved not only in the maintenance of a healthy vasculature but also in specific disease-associated processes. As eluded to in the different chapters, their activity in health and disease is regulated at all levels, from expression, RNA splicing, and stability to post-translational modifications, proteolytic activation, and protein-protein interactions of various kinds.

Furthermore, the different transcription factors reviewed exert their functions at different stages of atherosclerosis development and progression. At one end of this process are different types of blood flow providing an atheroprotective or an atheroprone environment, which either preserves endothelial function or induces endothelial activation and dysfunction. In addition, the control of vascular smooth muscle proliferation after vascular injury is important for neointima formation. During disease progression, B cells and macrophages play a role in the cellular composition inside the plaque. In final stages, plaque destabilization and rupture occur. One fatal consequence is vascular occlusion, leading to myocardial infarction or stroke.

Although we have described several aspects of how modulation of the activity of specific transcription factors in different cell types affects the various facets of atherosclerosis, this does not exclude that they regulate completely different processes in other cell types and other organs. Therefore, and due to pleiotropic outputs owing to their large number of target genes, global therapeutic activation or inhibition of specific transcription factors does not seem feasible. This goes along with the view of these proteins as being "undruggable," since such interventions are prone to have adverse side effects as exemplified in the case of peroxisome proliferator-activated receptors (135). An in-depth analysis of cell type-, disease-, and perhaps also stage-specific protein-protein interactions or target genes might open up avenues that are more promising. The increasing knowledge about the structural basis of transcription factor interactions with each other and other proteins might in the long run allow the design of drugs blocking such contact sites with high specificity (48).
Furthermore, the CRISPR/Cas system can be used not only for genome editing but also for the creation of transcriptional activators or repressors (36). The guide RNA directing the engineered Cas-derived transcriptional regulators to their target site is longer than most transcription factor recognition sites on DNA, which allows a much more specific regulation, perhaps also of single genes that are relevant for disease.

\section{Acknowledgments}

S.K. is a scholarship holder of the IRTG1902. This work was, in part, supported by the Deutsche Forschungsgemeinschaft (AL288/2-1 and IRTG1902 P1) to J.A., by NIH R01 HL107490 and P01 HL55798 to C.A.M., and by an NIH Immunology Training Grant to A.U. (2 T32 AI 7496-21). Single elements for figures were taken from the Powerpoint image bank of Servier Medical Art (www.servier .com/Powerpoint-image-bank), which is licensed under a Creative Commons Attribution 3.0 Unported License (http:// creativecommons.org/licenses/by/3.0).

\section{References}

1. Amoutzias GD, Robertson DL, Van de Peer Y, and Oliver SG. Choose your partners: dimerization in eukaryotic transcription factors. Trends Biochem Sci 33: 220-229, 2008.

2. Arias-Loza PA, Muehlfelder M, and Pelzer T. Estrogen and estrogen receptors in cardiovascular oxidative stress. Pflugers Arch 465: 739-746, 2013.

3. Atkins GB, Wang Y, Mahabeleshwar GH, Shi H, Gao H, Kawanami D, Natesan V, Lin Z, Simon DI, and Jain MK. Hemizygous deficiency of Krüppel-like factor 2 augments experimental atherosclerosis. Circ Res 103: 690-693, 2008.

4. Bauer V and Sotnikova R. Nitric oxide-the endotheliumderived relaxing factor and its role in endothelial functions. Gen Physiol Biophys 29: 319-340, 2010.

5. Bennett MR. Apoptosis of vascular smooth muscle cells in vascular remodelling and atherosclerotic plaque rupture. Cardiovasc Res 41: 361-368, 1999.

6. Bennett MR, Evan GI, and Schwartz SM. Apoptosis of human vascular smooth muscle cells derived from normal vessels and coronary atherosclerotic plaques. J Clin Invest 95: 2266-2274, 1995.

7. Bennett MR, Sinha S, and Owens GK. Vascular smooth muscle cells in atherosclerosis. Circ Res 118: 692-702, 2016.

8. Bieker JJ. Krüppel-like factors: three fingers in many pies. J Biol Chem 276: 34355-34358, 2001.

9. Birben E, Sahiner UM, Sackesen C, Erzurum S, and Kalayci O. Oxidative stress and antioxidant defense. World Allergy Organ J 5: 9-19, 2012.

10. Blanco FJ and Bernabeu C. The splicing factor SRSF1 as a marker for endothelial senescence. Front Physiol 3: 54, 2012.

11. Boglev Y, Wilanowski T, Caddy J, Parekh V, Auden A, Darido C, Hislop NR, Cangkrama M, Ting SB, and Jane $\mathrm{SM}$. The unique and cooperative roles of the Grainy headlike transcription factors in epidermal development reflect unexpected target gene specificity. Dev Biol 349: 512522, 2011.

12. Bourguet W, Germain P, and Gronemeyer H. Nuclear receptor ligand-binding domains: three-dimensional structures, 
molecular interactions and pharmacological implications. Trends Pharmacol Sci 21: 381-388, 2000.

13. Britton KA and Fox CS. Perivascular adipose tissue and vascular disease. Clin Lipidol 6: 79-91, 2011.

14. Bulleid NJ and Ellgaard L. Multiple ways to make disulfides. Trends Biochem Sci 36: 485-492, 2011.

15. Caballero AE. Endothelial dysfunction in obesity and insulin resistance: a road to diabetes and heart disease. Obes Res 11: 1278-1289, 2003.

16. Caddy J, Wilanowski T, Darido C, Dworkin S, Ting SB, Zhao Q, Rank G, Auden A, Srivastava S, Papenfuss TA, Murdoch JN, Humbert PO, Parekh V, Boulos N, Weber T, Zuo J, Cunningham JM, and Jane SM. Epidermal wound repair is regulated by the planar cell polarity signaling pathway. Dev Cell 19: 138-147, 2010.

17. Cai $\mathrm{H}$ and Harrison DG. Endothelial dysfunction in cardiovascular diseases: the role of oxidant stress. Circ Res 87: 840-844, 2000.

18. Campbell KA, Lipinski MJ, Doran AC, Skaflen MD, Fuster V, and McNamara CA. Lymphocytes and the adventitial immune response in atherosclerosis. Circ Res 110: 889-900, 2012.

19. Carr SM, Poppy Roworth A, Chan C, and La Thangue NB. Post-translational control of transcription factors: methylation ranks highly. FEBS $J$ 282: 4450-4465, 2015.

20. Chakrabarti S and Davidge ST. G-protein coupled receptor 30 (GPR30): a novel regulator of endothelial inflammation. PLoS One 7: e52357, 2012.

21. Chappell DC, Varner SE, Nerem RM, Medford RM, and Alexander RW. Oscillatory shear stress stimulates adhesion molecule expression in cultured human endothelium. Circ Res 82: 532-539, 1998.

22. Chatzizisis YS, Coskun AU, Jonas M, Edelman ER, Feldman CL, and Stone PH. Role of endothelial shear stress in the natural history of coronary atherosclerosis and vascular remodeling: molecular, cellular, and vascular behavior. J Am Coll Cardiol 49: 2379-2393, 2007.

23. Chen B, Han BH, Sun XH, and Lim RW. Inhibition of muscle-specific gene expression by Id3: requirement of the C-terminal region of the protein for stable expression and function. Nucleic Acids Res 25: 423-430, 1997.

24. Chen SJ, Li H, Durand J, Oparil S, and Chen YF. Estrogen reduces myointimal proliferation after balloon injury of rat carotid artery. Circulation 93: 577-584, 1996.

25. Chen Z, Wsen L, Martin M, Hsu CY, Fang L, Lin FM, Lin TY, Geary MJ, Geary GG, Zhao Y, Johnson DA, Chen JW, Lin SJ, Chien S, Huang HD, Miller YI, Huang PH, and Shyy JY. Oxidative stress activates endothelial innate immunity via sterol regulatory element binding protein 2 (SREBP2) transactivation of microRNA-92a. Circulation 131: 805-814, 2015.

26. Chinetti-Gbaguidi G, Colin S, and Staels B. Macrophage subsets in atherosclerosis. Nat Rev Cardiol 12: 10-17, 2015.

27. Clempus RE and Griendling KK. Reactive oxygen species signaling in vascular smooth muscle cells. Cardiovasc Res 71: 216-225, 2006.

28. Collins T, Read MA, Neish AS, Whitley MZ, Thanos D, and Maniatis T. Transcriptional regulation of endothelial cell adhesion molecules: NF-kappa B and cytokineinducible enhancers. FASEB J 9: 899-909, 1995.

29. Daemen MJ, Lombardi DM, Bosman FT, and Schwartz SM. Angiotensin II induces smooth muscle cell proliferation in the normal and injured rat arterial wall. Circ Res 68: 450456, 1991.

30. Das $\mathrm{C}$ and Kundu TK. Transcriptional regulation by the acetylation of nonhistone proteins in humans-a new target for therapeutics. IUBMB Life 57: 137-149, 2005.

31. Deanfield JE, Halcox JP, and Rabelink TJ. Endothelial function and dysfunction: testing and clinical relevance. Circulation 115: 1285-1295, 2007.

32. Deed RW, Jasiok M, and Norton JD. Attenuated function of a variant form of the helix-loop-helix protein, Id-3, generated by an alternative splicing mechanism. FEBS Lett 393: 113-116, 1996.

33. Dekker RJ, van Soest S, Fontijn RD, Salamanca S, de Groot PG, VanBavel E, Pannekoek H, and Horrevoets AJ. Prolonged fluid shear stress induces a distinct set of endothelial cell genes, most specifically lung Krüppel-like factor (KLF2). Blood 100: 1689-1698, 2002.

34. Denninger JW and Marletta MA. Guanylate cyclase and the .NO/cGMP signaling pathway. Biochim Biophys Acta 1411: 334-350, 1999.

35. Devries-Seimon T, Li Y, Yao PM, Stone E, Wang Y, Davis RJ, Flavell R, and Tabas I. Cholesterol-induced macrophage apoptosis requires ER stress pathways and engagement of the type A scavenger receptor. J Cell Biol 171: 61-73, 2005.

36. Dominguez AA, Lim WA, and Qi LS. Beyond editing: repurposing CRISPR-Cas9 for precision genome regulation and interrogation. Nat Rev Mol Cell Biol 17: 5-15, 2016.

37. Doran AC, Lehtinen AB, Meller N, Lipinski MJ, Slayton RP, Oldham SN, Skaflen MD, Yeboah J, Rich SS, Bowden DW, and McNamara CA. Id3 is a novel atheroprotective factor containing a functionally significant single-nucleotide polymerism associated with intimamedia thickness in humans. Circ Res 106: 1303-1311, 2010.

38. Doran AC, Lipinski MJ, Oldham SN, Garmey JC, Campbell KA, Skaflen MD, Cutchins A, Lee DJ, Glover DK, Kelly KA, Galkina EV, Ley K, Witztum JL, Tsimikas $\mathrm{S}$, Bender TP, and McNamara CA. B-cell aortic homing and atheroprotection depend on Id3. Circ Res 110: e1e12, 2012.

39. Eletto D, Chevet E, Argon Y, and Appenzeller-Herzog C. Redox controls UPR to control redox. J Cell Sci 127: 3649-3658, 2014.

40. Erbay E, Babaev VR, Mayers JR, Makowski L, Charles KN, Snitow ME, Fazio S, Wiest MM, Watkins SM, Linton MF, and Hotamisligil GS. Reducing endoplasmic reticulum stress through a macrophage lipid chaperone alleviates atherosclerosis. Nat Med 15: 1383-1391, 2009.

41. Fang Y and Davies PF. Site-specific microRNA-92a regulation of Krüppel-like factors 4 and 2 in atherosusceptible endothelium. Arterioscler Thromb Vasc Biol 32: 979-987, 2012.

42. Favero G, Paganelli C, Buffoli B, Rodella LF, and Rezzani R. Endothelium and its alterations in cardiovascular diseases: life style intervention. Biomed Res Int 2014: 801896, 2014.

43. Febbraio M, Guy E, and Silverstein RL. Stem cell transplantation reveals that absence of macrophage CD36 is protective against atherosclerosis. Arterioscler Thromb Vasc Biol 24: 2333-2338, 2004.

44. Feng B, Yao PM, Li Y, Devlin CM, Zhang D, Harding HP, Sweeney M, Rong JX, Kuriakose G, Fisher EA, Marks AR, Ron D, and Tabas I. The endoplasmic reticulum 
is the site of cholesterol-induced cytotoxicity in macrophages. Nat Cell Biol 5: 781-792, 2003.

45. Figtree GA, McDonald D, Watkins H, and Channon KM. Truncated estrogen receptor alpha $46-\mathrm{kDa}$ isoform in human endothelial cells: relationship to acute activation of nitric oxide synthase. Circulation 107: 120-126, 2003.

46. Finkel T. Signal transduction by reactive oxygen species. J Cell Biol 194: 7-15, 2011.

47. Fiorentino TV, Prioletta A, Zuo P, and Folli F. Hyperglycemia-induced oxidative stress and its role in diabetes mellitus related cardiovascular diseases. Curr Pharm Des 19: 5695-5703, 2013.

48. Fontaine F, Overman J, and Francois M. Pharmacological manipulation of transcription factor protein-protein interactions: opportunities and obstacles. Cell Regen (Lond) 4: 2, 2015

49. Forrest $\mathrm{S}$ and McNamara C. Id family of transcription factors and vascular lesion formation. Arterioscler Thromb Vasc Biol 24: 2014-2020, 2004.

50. Forrest ST, Barringhaus KG, Perlegas D, Hammarskjold $\mathrm{ML}$, and McNamara CA. Intron retention generates a novel Id3 isoform that inhibits vascular lesion formation. $J$ Biol Chem 279: 32897-32903, 2004.

51. Förstermann U. Oxidative stress in vascular disease: causes, defense mechanisms and potential therapies. Nat Clin Pract Cardiovasc Med 5: 338-349, 2008.

52. Frankel AD and Kim PS. Modular structure of transcription factors: implications for gene regulation. Cell 65: 717-719, 1991.

53. Frietze $S$ and Farnham PJ. Transcription factor effector domains. Subcell Biochem 52: 261-277, 2011.

54. Fulton D, Gratton JP, McCabe TJ, Fontana J, Fujio Y, Walsh K, Franke TF, Papapetropoulos A, and Sessa WC. Regulation of endothelium-derived nitric oxide production by the protein kinase Akt. Nature 399: 597-601, 1999.

55. Furukawa S, Fujita T, Shimabukuro M, Iwaki M, Yamada Y, Nakajima Y, Nakayama O, Makishima M, Matsuda M, and Shimomura I. Increased oxidative stress in obesity and its impact on metabolic syndrome. J Clin Invest 114: 1752-1761, 2004.

56. Geng F, Wenzel S, and Tansey WP. Ubiquitin and proteasomes in transcription. Annu Rev Biochem 81: 177201, 2012.

57. Gill G. Something about SUMO inhibits transcription. Curr Opin Genet Dev 15: 536-541, 2005.

58. Gomez D and Owens GK. Smooth muscle cell phenotypic switching in atherosclerosis. Cardiovasc Res 95: 156-164, 2012.

59. Gräbner R, Lötzer K, Döpping S, Hildner M, Radke D, Beer M, Spanbroek R, Lippert B, Reardon CA, Getz GS, Fu YX, Hehlgans T, Mebius RE, van der Wall M, Kruspe D, Englert C, Lovas A, Hu D, Randolph GJ, Weih F, and Habenicht AJ. Lymphotoxin beta receptor signaling promotes tertiary lymphoid organogenesis in the aorta adventitia of aged ApoE-/- mice. J Exp Med 206: 233-248, 2009.

60. Grandori C, Cowley SM, James LP, and Eisenman RN. The Myc/Max/Mad network and the transcriptional control of cell behavior. Annu Rev Cell Dev Biol 16: 653-699, 2000.

61. Grodstein F, Manson JE, and Stampfer MJ. Hormone therapy and coronary heart disease: the role of time since menopause and age at hormone initiation. J Womens Health (Larchmt) 15: 35-44, 2006.
62. Gu Y, Lee W, and Shen J. Site-2 protease responds to oxidative stress and regulates oxidative injury in mammalian cells. Sci Rep 4: 6268, 2014.

63. Guardiola-Serrano F, Haendeler J, Lukosz M, Sturm K, von Melchner H, and Altschmied J. Gene trapping identifies a putative tumor suppressor and a new inducer of cell migration. Biochem Biophys Res Commun 376: 748752, 2008.

64. Gustavsson P, Greene ND, Lad D, Pauws E, de Castro SC, Stanier P, and Copp AJ. Increased expression of Grainyhead-like-3 rescues spina bifida in a folate-resistant mouse model. Hum Mol Genet 16: 2640-2646, 2007.

65. Haendeler J, Mlynek A, Büchner N, Lukosz M, Graf M, Guettler C, Jakob S, Farrokh S, Kunze K, Goy C, Guardiola-Serrano F, Schaal H, Cortese-Krott M, Deenen R, Köhrer K, Winkler C, and Altschmied J. Two isoforms of Sister-Of-Mammalian Grainyhead have opposing functions in endothelial cells and in vivo. Arterioscler Thromb Vasc Biol 33: 1639-1646, 2013.

66. Hai $\mathrm{T}$ and Curran T. Cross-family dimerization of transcription factors Fos/Jun and ATF/CREB alters DNA binding specificity. Proc Natl Acad Sci U S A 88: 37203724, 1991.

67. Hai TW, Liu F, Coukos WJ, and Green MR. Transcription factor ATF cDNA clones: an extensive family of leucine zipper proteins able to selectively form DNA-binding heterodimers. Genes Dev 3: 2083-2090, 1989.

68. Haidari M, Ali M, Gangehei L, Chen M, Zhang W, and Cybulsky MI. Increased oxidative stress in atherosclerosispredisposed regions of the mouse aorta. Life Sci 87: 100110, 2010.

69. Hamik A and Jain MK. MiRrored regulation of KLF2 and KLF4. Arterioscler Thromb Vasc Biol 32: 839-840, 2012.

70. Hamik A, Lin Z, Kumar A, Balcells M, Sinha S, Katz J, Feinberg MW, Gerzsten RE, Edelman ER, and Jain MK. Kruppel-like factor 4 regulates endothelial inflammation. J Biol Chem 282: 13769-13779, 2007.

71. Hansson GK and Libby P. The immune response in atherosclerosis: a double-edged sword. Nat Rev Immunol 6: 508-519, 2006.

72. Harrison D, Griendling KK, Landmesser U, Hornig B, and Drexler H. Role of oxidative stress in atherosclerosis. Am J Cardiol 91: 7A-11A, 2003.

73. Hastings NE, Simmers MB, McDonald OG, Wamhoff $\mathrm{BR}$, and Blackman BR. Atherosclerosis-prone hemodynamics differentially regulates endothelial and smooth muscle cell phenotypes and promotes pro-inflammatory priming. Am J Physiol Cell Physiol 293: C1824-C1833, 2007.

74. Haynes MP, Li L, Sinha D, Russell KS, Hisamoto K, Baron R, Collinge M, Sessa WC, and Bender JR. Src kinase mediates phosphatidylinositol 3-kinase/Akt-dependent rapid endothelial nitric-oxide synthase activation by estrogen. J Biol Chem 278: 2118-2123, 2003.

75. Haynes MP, Sinha D, Russell KS, Collinge M, Fulton D, Morales-Ruiz M, Sessa WC, and Bender JR. Membrane estrogen receptor engagement activates endothelial nitric oxide synthase via the PI3-kinase-Akt pathway in human endothelial cells. Circ Res 87: 677-682, 2000.

76. Haze K, Yoshida H, Yanagi H, Yura T, and Mori K. Mammalian transcription factor ATF6 is synthesized as a transmembrane protein and activated by proteolysis in response to endoplasmic reticulum stress. Mol Biol Cell 10: 3787-3799, 1999. 
77. Hegyi L, Skepper JN, Cary NR, and Mitchinson MJ. Foam cell apoptosis and the development of the lipid core of human atherosclerosis. J Pathol 180: 423-429, 1996.

78. Hislop NR, Caddy J, Ting SB, Auden A, Vasudevan S, King SL, Lindeman GJ, Visvader JE, Cunningham JM, and Jane SM. Grhl3 and Lmo4 play coordinate roles in epidermal migration. Dev Biol 321: 263-272, 2008.

79. Hodgin JB, Krege JH, Reddick RL, Korach KS, Smithies $\mathrm{O}$, and Maeda N. Estrogen receptor alpha is a major mediator of 17beta-estradiol's atheroprotective effects on lesion size in Apoe-/- mice. J Clin Invest 107: 333-340, 2001.

80. Hoffmann J, Haendeler J, Aicher A, Rössig L, Vasa M, Zeiher AM, and Dimmeler S. Aging enhances the sensitivity of endothelial cells toward apoptotic stimuli: important role of nitric oxide. Circ Res 89: 709-715, 2001.

81. Holmström KM and Finkel T. Cellular mechanisms and physiological consequences of redox-dependent signalling. Nat Rev Mol Cell Biol 15: 411-421, 2014.

82. Hoppe T, Rape M, and Jentsch S. Membrane-bound transcription factors: regulated release by RIP or RUP. Curr Opin Cell Biol 13: 344-348, 2001.

83. Horvath CM. STAT proteins and transcriptional responses to extracellular signals. Trends Biochem Sci 25: 496-502, 2000.

84. Hotamisligil GS. Endoplasmic reticulum stress and atherosclerosis. Nat Med 16: 396-399, 2010.

85. Huang F, Yin J, Li K, Li Y, Qi H, Fang L, Yuan C, Liu W, Wang $\mathrm{M}$, and Li X. GPR30 decreases with vascular aging and promotes vascular smooth muscle cells maintaining differentiated phenotype and suppressing migration via activation of ERK1/2. Onco Targets Ther 9: 3415-3422, 2016.

86. Hummasti S and Hotamisligil GS. Endoplasmic reticulum stress and inflammation in obesity and diabetes. Circ Res 107: 579-591, 2010.

87. Hwang J, Ing MH, Salazar A, Lassegue B, Griendling K, Navab M, Sevanian A, and Hsiai TK. Pulsatile versus oscillatory shear stress regulates NADPH oxidase subunit expression: implication for native LDL oxidation. Circ Res 93: 1225-1232, 2003.

88. Hwang J, Saha A, Boo YC, Sorescu GP, McNally JS, Holland SM, Dikalov S, Giddens DP, Griendling KK, Harrison DG, and Jo H. Oscillatory shear stress stimulates endothelial production of O2- from $\mathrm{p} 47$ phox-dependent NAD(P)H oxidases, leading to monocyte adhesion. $J$ Biol Chem 278: 47291-47298, 2003.

89. Impey S, McCorkle SR, Cha-Molstad H, Dwyer JM, Yochum GS, Boss JM, McWeeney S, Dunn JJ, Mandel G, and Goodman RH. Defining the CREB regulon: a genome-wide analysis of transcription factor regulatory regions. Cell 119: 1041-1054, 2004.

90. Khalil RA. Estrogen, vascular estrogen receptor and hormone therapy in postmenopausal vascular disease. Biochem Pharmacol 86: 1627-1642, 2013.

91. Kuchibhotla S, Vanegas D, Kennedy DJ, Guy E, Nimako G, Morton RE, and Febbraio M. Absence of CD36 protects against atherosclerosis in ApoE knock-out mice with no additional protection provided by absence of scavenger receptor A I/II. Cardiovasc Res 78: 185-196, 2008.

92. Kunjathoor VV, Febbraio M, Podrez EA, Moore KJ, Andersson L, Koehn S, Rhee JS, Silverstein R, Hoff HF, and Freeman MW. Scavenger receptors class A-I/II and CD36 are the principal receptors responsible for the up- take of modified low density lipoprotein leading to lipid loading in macrophages. J Biol Chem 277: 49982-49988, 2002.

93. Kyaw T, Tay C, Krishnamurthi S, Kanellakis P, Agrotis A, Tipping P, Bobik A, and Toh BH. B1a B lymphocytes are atheroprotective by secreting natural IgM that increases IgM deposits and reduces necrotic cores in atherosclerotic lesions. Circ Res 109: 830-840, 2011.

94. Laufs U, La Fata V, Plutzky J, and Liao JK. Upregulation of endothelial nitric oxide synthase by HMG CoA reductase inhibitors. Circulation 97: 1129-1135, 1998.

95. Leal J, Luengo-Fernandez R, Gray A, Petersen S, and Rayner M. Economic burden of cardiovascular diseases in the enlarged European Union. Eur Heart J 27: 1610-1619, 2006.

96. Lee JS, Yu Q, Shin JT, Sebzda E, Bertozzi C, Chen M, Mericko P, Stadtfeld M, Zhou D, Cheng L, Graf T, MacRae CA, Lepore JJ, Lo CW, and Kahn ML. Klf2 is an essential regulator of vascular hemodynamic forces in vivo. Dev Cell 11: 845-857, 2006.

97. Lee TI and Young RA. Transcriptional regulation and its misregulation in disease. Cell 152: 1237-1251, 2013.

98. Lerner DJ and Kannel WB. Patterns of coronary heart disease morbidity and mortality in the sexes: a 26-year follow-up of the Framingham population. Am Heart J 111: 383-390, 1986.

99. Levin ER and Hammes SR. Nuclear receptors outside the nucleus: extranuclear signalling by steroid receptors. Nat Rev Mol Cell Biol 17: 783-797, 2016.

100. Li L, Haynes MP, and Bender JR. Plasma membrane localization and function of the estrogen receptor alpha variant (ER46) in human endothelial cells. Proc Natl Acad Sci U S A 100: 4807-4812, 2003.

101. Li L, Hisamoto K, Kim KH, Haynes MP, Bauer PM, Sanjay A, Collinge M, Baron R, Sessa WC, and Bender JR. Variant estrogen receptor-c-Src molecular interdependence and c-Src structural requirements for endothelial NO synthase activation. Proc Natl Acad Sci U S A 104: 16468-16473, 2007.

102. Libby P, Ridker PM, and Hansson GK. Progress and challenges in translating the biology of atherosclerosis. Nature 473: 317-325, 2011.

103. Lipinski MJ, Campbell KA, Duong SQ, Welch TJ, Garmey JC, Doran AC, Skaflen MD, Oldham SN, Kelly KA, and McNamara CA. Loss of Id3 increases VCAM-1 expression, macrophage accumulation, and atherogenesis in Ldlr-/- mice. Arterioscler Thromb Vasc Biol 32: 28552861, 2012.

104. Lloyd-Jones DM and Bloch KD. The vascular biology of nitric oxide and its role in atherogenesis. Anпи Rev Med 47: 365-375, 1996.

105. Loschen G, Azzi A, Richter C, and Flohé L. Superoxide radicals as precursors of mitochondrial hydrogen peroxide. FEBS Lett 42: 68-72, 1974.

106. Lukosz M, Jakob S, Büchner N, Zschauer TC, Altschmied $\mathrm{J}$, and Haendeler J. Nuclear redox signaling. Antioxid Redox Signal 12: 713-742, 2010.

107. Lukosz M, Mlynek A, Czypiorski P, Altschmied J, and Haendeler J. The transcription factor Grainyhead like 3 (GRHL3) affects endothelial cell apoptosis and migration in a NO-dependent manner. Biochem Biophys Res Commun 412: 648-653, 2011.

108. Lundberg B. Chemical composition and physical state of lipid deposits in atherosclerosis. Atherosclerosis 56: 93110, 1985. 
109. Lüscher B. Function and regulation of the transcription factors of the Myc/Max/Mad network. Gene 277: 1-14, 2001.

110. Madamanchi NR and Runge MS. Redox signaling in cardiovascular health and disease. Free Radic Biol Med 61: 473-501, 2013.

111. Malhotra D, Portales-Casamar E, Singh A, Srivastava S, Arenillas D, Happel C, Shyr C, Wakabayashi N, Kensler TW, Wasserman WW, and Biswal S. Global mapping of binding sites for Nrf2 identifies novel targets in cell survival response through ChIP-Seq profiling and network analysis. Nucleic Acids Res 38: 5718-5734, 2010.

112. Malhotra JD and Kaufman RJ. Endoplasmic reticulum stress and oxidative stress: a vicious cycle or a doubleedged sword? Antioxid Redox Signal 9: 2277-2293, 2007.

113. Mangelsdorf DJ and Evans RM. The RXR heterodimers and orphan receptors. Cell 83: 841-850, 1995.

114. Manichaikul A, Rich SS, Perry H, Yeboah J, Law M, Davis M, Parker M, Ragosta M, Connelly JJ, McNamara $\mathrm{CA}$, and Taylor AM. A functionally significant polymorphism in ID3 is associated with human coronary pathology. PLoS One 9: e90222, 2014.

115. Massari ME and Murre C. Helix-loop-helix proteins: regulators of transcription in eucaryotic organisms. Mol Cell Biol 20: 429-440, 2000.

116. Mathur P, Ostadal B, Romeo F, and Mehta JL. Genderrelated differences in atherosclerosis. Cardiovasc Drugs Ther 29: 319-327, 2015.

117. Matsumura ME, Li F, Berthoux L, Wei B, Lobe DR, Jeon C, Hammarskjold ML, and McNamara CA. Vascular injury induces posttranscriptional regulation of the Id3 gene: cloning of a novel Id3 isoform expressed during vascular lesion formation in rat and human atherosclerosis. Arterioscler Thromb Vasc Biol 21: 752-758, 2001.

118. Matsushita H, Morishita R, Kida I, Aoki M, Hayashi S, Tomita N, Yamamoto K, Moriguchi A, Noda A, Kaneda Y, Higaki J, and Ogihara T. Inhibition of growth of human vascular smooth muscle cells by overexpression of $\mathrm{p} 21$ gene through induction of apoptosis. Hypertension 31: 493-498, 1998.

119. McNally JS, Davis ME, Giddens DP, Saha A, Hwang J, Dikalov S, Jo H, and Harrison DG. Role of xanthine oxidoreductase and $\mathrm{NAD}(\mathrm{P}) \mathrm{H}$ oxidase in endothelial superoxide production in response to oscillatory shear stress. $\mathrm{Am}$ J Physiol Heart Circ Physiol 285: H2290-H2297, 2003.

120. Merz AA and Cheng S. Sex differences in cardiovascular ageing. Heart 102: 825-831, 2016.

121. Meyer MR and Barton M. Estrogens and coronary artery disease: new clinical perspectives. Adv Pharmacol 77: 307-360, 2016.

122. Meyer MR, Fredette NC, Howard TA, Hu C, Ramesh C, Daniel C, Amann K, Arterburn JB, Barton M, and Prossnitz ER. G protein-coupled estrogen receptor protects from atherosclerosis. Sci Rep 4: 7564, 2014.

123. Miller AP, Feng W, Xing D, Weathington NM, Blalock JE, Chen YF, and Oparil S. Estrogen modulates inflammatory mediator expression and neutrophil chemotaxis in injured arteries. Circulation 110: 1664-1669, 2004.

124. Milstone DS, Ilyama M, Chen M, O'Donnell P, Davis VM, Plutzky J, Brown JD, Haldar SM, Siu A, Lau AC, Zhu SN, Basheer MF, Collins T, Jongstra-Bilen J, and Cybulsky MI. Differential role of an NF-kappaB transcriptional response element in endothelial versus intimal cell VCAM-1 expression. Circ Res 117: 166-177, 2015.

125. Mimura $\mathbf{J}$ and Itoh K. Role of Nrf2 in the pathogenesis of atherosclerosis. Free Radic Biol Med 88: 221-232, 2015.
126. Minamino $\mathrm{T}$ and Komuro I. Vascular cell senescence: contribution to atherosclerosis. Circ Res 100: 15-26, 2007.

127. Moras D and Gronemeyer H. The nuclear receptor ligandbinding domain: structure and function. Curr Opin Cell Biol 10: 384-391, 1998.

128. Mori M, Tsukahara F, Yoshioka T, Irie K, and Ohta H. Suppression by 17 beta-estradiol of monocyte adhesion to vascular endothelial cells is mediated by estrogen receptors. Life Sci 75: 599-609, 2004.

129. Mosca L, Benjamin EJ, Berra K, Bezanson JL, Dolor RJ, Lloyd-Jones DM, Newby LK, Pina IL, Roger VL, Shaw LJ, Zhao D, Beckie TM, Bushnell C, D'Armiento J, KrisEtherton PM, Fang J, Ganiats TG, Gomes AS, Gracia CR, Haan CK, Jackson EA, Judelson DR, Kelepouris E, Lavie CJ, Moore A, Nussmeier NA, Ofili E, Oparil S, Ouyang P, Pinn VW, Sherif K, Smith SC, Jr., Sopko G, ChandraStrobos N, Urbina EM, Vaccarino V, and Wenger NK. Effectiveness-based guidelines for the prevention of cardiovascular disease in women-2011 update: a guideline from the American Heart Association. Circulation 123: 1243-1262, 2011.

130. Mozaffarian D, Benjamin EJ, Go AS, Arnett DK, Blaha MJ, Cushman M, Das SR, de Ferranti S, Despres JP, Fullerton HJ, Howard VJ, Huffman MD, Isasi CR, Jimenez MC, Judd SE, Kissela BM, Lichtman JH, Lisabeth LD, Liu S, Mackey RH, Magid DJ, McGuire DK, Mohler ER, 3rd, Moy CS, Muntner P, Mussolino ME, Nasir K, Neumar RW, Nichol G, Palaniappan L, Pandey DK, Reeves MJ, Rodriguez CJ, Rosamond W, Sorlie PD, Stein J, Towfighi A, Turan TN, Virani SS, Woo D, Yeh RW, Turner MB, American Heart Association Statistics Committee, and Stroke Statistics Subcommittee. Heart disease and stroke statistics-2016 update: a report from the American Heart Association. Circulation 133: e38-e360, 2016.

131. Mueller C, Baudler S, Welzel H, Bohm M, and Nickenig G. Identification of a novel redox-sensitive gene, Id3, which mediates angiotensin II-induced cell growth. Circulation 105: 2423-2428, 2002.

132. Munoz-Espin D and Serrano M. Cellular senescence: from physiology to pathology. Nat Rev Mol Cell Biol 15: 482496, 2014.

133. Myoishi M, Hao H, Minamino T, Watanabe K, Nishihira K, Hatakeyama K, Asada Y, Okada K, Ishibashi-Ueda H, Gabbiani G, Bochaton-Piallat ML, Mochizuki N, and Kitakaze M. Increased endoplasmic reticulum stress in atherosclerotic plaques associated with acute coronary syndrome. Circulation 116: 1226-1233, 2007.

134. Nadanaka S, Okada T, Yoshida H, and Mori K. Role of disulfide bridges formed in the luminal domain of ATF6 in sensing endoplasmic reticulum stress. Mol Cell Biol 27: 1027-1043, 2007

135. Nevin DK, Lloyd DG, and Fayne D. Rational targeting of peroxisome proliferating activated receptor subtypes. Curr Med Chem 18: 5598-5623, 2011.

136. Nickenig G, Baudler S, Muller C, Werner C, Werner N, Welzel H, Strehlow K, and Bohm M. Redox-sensitive vascular smooth muscle cell proliferation is mediated by GKLF and Id3 in vitro and in vivo. FASEB $J$ 16: 10771086, 2002.

137. Norton JD. ID helix-loop-helix proteins in cell growth, differentiation and tumorigenesis. J Cell Sci 113 (Pt 22): 3897-3905, 2000. 
138. Oakes SA and Papa FR. The role of endoplasmic reticulum stress in human pathology. Annu Rev Pathol 10: 173194, 2015.

139. Ohnesorge N, Viemann D, Schmidt N, Czymai T, Spiering D, Schmolke M, Ludwig S, Roth J, Goebeler M, and Schmidt M. Erk5 activation elicits a vasoprotective endothelial phenotype via induction of Krüppel-like factor 4 (KLF4). J Biol Chem 285: 26199-26210, 2010.

140. Owens GK, Kumar MS, and Wamhoff BR. Molecular regulation of vascular smooth muscle cell differentiation in development and disease. Physiol Rev 84: 767-801, 2004.

141. Ozcan L and Tabas I. Role of endoplasmic reticulum stress in metabolic disease and other disorders. Апnи Rev Med 63: 317-328, 2012.

142. Palmer AK, Tchkonia T, LeBrasseur NK, Chini EN, Xu M, and Kirkland JL. Cellular senescence in type 2 diabetes: a therapeutic opportunity. Diabetes 64: 2289-2298, 2015.

143. Palmer RM, Ashton DS, and Moncada S. Vascular endothelial cells synthesize nitric oxide from L-arginine. Nature 333: 664-666, 1988.

144. Palmer RM, Ferrige AG, and Moncada S. Nitric oxide release accounts for the biological activity of endotheliumderived relaxing factor. Nature 327: 524-526, 1987.

145. Pamukcu B, Lip GY, and Shantsila E. The nuclear factor-kappa B pathway in atherosclerosis: a potential therapeutic target for atherothrombotic vascular disease. Thromb Res 128: 117-123, 2011.

146. Parmar KM, Larman HB, Dai G, Zhang Y, Wang ET, Moorthy SN, Kratz JR, Lin Z, Jain MK, Gimbrone MA, Jr., and Garcia-Cardena G. Integration of flow-dependent endothelial phenotypes by Kruppel-like factor 2. J Clin Invest 116: 49-58, 2006.

147. Pateras I, Giaginis C, Tsigris C, Patsouris E, and Theocharis S. NF-kappaB signaling at the crossroads of inflammation and atherogenesis: searching for new therapeutic links. Expert Opin Ther Targets 18: 10891101, 2014.

148. Perry HM, Bender TP, and McNamara CA. B cell subsets in atherosclerosis. Front Immunol 3: 373, 2012.

149. Pick R, Stamler J, Rodbard S, and Katz LN. The inhibition of coronary atherosclerosis by estrogens in cholesterol-fed chicks. Circulation 6: 276-280, 1952.

150. Polytarchou C, Iliopoulos D, Hatziapostolou M, Kottakis F, Maroulakou I, Struhl K, and Tsichlis PN. Akt2 regulates all Akt isoforms and promotes resistance to hypoxia through induction of miR-21 upon oxygen deprivation. Cancer Res 71: 4720-4731, 2011.

151. Prossnitz ER, Arterburn JB, Smith HO, Oprea TI, Sklar LA, and Hathaway HJ. Estrogen signaling through the transmembrane $\mathrm{G}$ protein-coupled receptor GPR30. Annu Rev Physiol 70: 165-190, 2008.

152. Rao GN and Berk BC. Active oxygen species stimulate vascular smooth muscle cell growth and proto-oncogene expression. Circ Res 70: 593-599, 1992.

153. Rifat Y, Parekh V, Wilanowski T, Hislop NR, Auden A, Ting SB, Cunningham JM, and Jane SM. Regional neural tube closure defined by the Grainy head-like transcription factors. Dev Biol 345: 237-245, 2010.

154. Robertson G, Hirst M, Bainbridge M, Bilenky M, Zhao Y, Zeng T, Euskirchen G, Bernier B, Varhol R, Delaney A, Thiessen N, Griffith OL, He A, Marra M, Snyder M, and Jones S. Genome-wide profiles of STAT1 DNA association using chromatin immunoprecipitation and massively parallel sequencing. Nat Methods 4: 651-657, 2007.
155. Robinson-Rechavi M, Escriva Garcia H, and Laudet V. The nuclear receptor superfamily. J Cell Sci 116: 585586, 2003.

156. Rodriguez E, Lopez R, Paez A, Masso F, and Montano LF. 17Beta-estradiol inhibits the adhesion of leukocytes in TNF-alpha stimulated human endothelial cells by blocking IL-8 and MCP-1 secretion, but not its transcription. Life Sci 71: 2181-2193, 2002.

157. Ruzinova MB and Benezra R. Id proteins in development, cell cycle and cancer. Trends Cell Biol 13: 410-418, 2003.

158. Sano R and Reed JC. ER stress-induced cell death mechanisms. Biochim Biophys Acta 1833: 3460-3470, 2013.

159. Santos CX, Tanaka LY, Wosniak J, and Laurindo FR. Mechanisms and implications of reactive oxygen species generation during the unfolded protein response: roles of endoplasmic reticulum oxidoreductases, mitochondrial electron transport, and NADPH oxidase. Antioxid Redox Signal 11: 2409-2427, 2009.

160. Schieber M and Chandel NS. ROS function in redox signaling and oxidative stress. Curr Biol 24: R453-R462, 2014.

161. Schroeder P, Popp R, Wiegand B, Altschmied J, and Haendeler J. Nuclear redox-signaling is essential for apoptosis inhibition in endothelial cells-important role for nuclear thioredoxin-1. Arterioscler Thromb Vasc Biol 27: 2325-2331, 2007.

162. Schulz E, Jansen T, Wenzel P, Daiber A, and Munzel T. Nitric oxide, tetrahydrobiopterin, oxidative stress, and endothelial dysfunction in hypertension. Antioxid Redox Signal 10: 1115-1126, 2008.

163. Scull CM and Tabas I. Mechanisms of ER stress-induced apoptosis in atherosclerosis. Arterioscler Thromb Vasc Biol 31: 2792-2797, 2011.

164. Seet BT, Dikic I, Zhou MM, and Pawson T. Reading protein modifications with interaction domains. Nat Rev Mol Cell Biol 7: 473-483, 2006.

165. Segre JA, Bauer C, and Fuchs E. Klf4 is a transcription factor required for establishing the barrier function of the skin. Nat Genet 22: 356-360, 1999.

166. Selzman CH, Gaynor JS, Turner AS, Johnson SM, Horwitz LD, Whitehill TA, and Harken AH. Ovarian ablation alone promotes aortic intimal hyperplasia and accumulation of fibroblast growth factor. Circulation 98: 2049-2054, 1998.

167. Sena CM, Pereira AM, and Seica R. Endothelial dysfunction-a major mediator of diabetic vascular disease. Biochim Biophys Acta 1832: 2216-2231, 2013.

168. SenBanerjee S, Lin Z, Atkins GB, Greif DM, Rao RM, Kumar A, Feinberg MW, Chen Z, Simon DI, Luscinskas FW, Michel TM, Gimbrone MA, Jr., Garcia-Cardena G, and Jain MK. KLF2 Is a novel transcriptional regulator of endothelial proinflammatory activation. J Exp Med 199: 1305-1315, 2004.

169. Shaw PX, Hörkkö S, Chang MK, Curtiss LK, Palinski W, Silverman GJ, and Witztum JL. Natural antibodies with the T15 idiotype may act in atherosclerosis, apoptotic clearance, and protective immunity. J Clin Invest 105: 1731-1740, 2000.

170. Sheppard KA, Rose DW, Haque ZK, Kurokawa R, McInerney E, Westin S, Thanos D, Rosenfeld MG, Glass CK, and Collins T. Transcriptional activation by NF-kappaB requires multiple coactivators. Mol Cell Biol 19: 63676378, 1999.

171. Shu HB, Agranoff AB, Nabel EG, Leung K, Duckett CS, Neish AS, Collins T, and Nabel GJ. Differential regulation of vascular cell adhesion molecule 1 gene expression by 
specific NF-kappa B subunits in endothelial and epithelial cells. Mol Cell Biol 13: 6283-6289, 1993.

172. Simoncini T, Maffei S, Basta G, Barsacchi G, Genazzani AR, Liao JK, and De Caterina R. Estrogens and glucocorticoids inhibit endothelial vascular cell adhesion molecule-1 expression by different transcriptional mechanisms. Circ Res 87: 19-25, 2000.

173. Soldaini E, John S, Moro S, Bollenbacher J, Schindler U, and Leonard WJ. DNA binding site selection of dimeric and tetrameric Stat5 proteins reveals a large repertoire of divergent tetrameric Stat5a binding sites. Mol Cell Biol 20: 389-401, 2000.

174. Suske G, Bruford E, and Philipsen S. Mammalian SP/KLF transcription factors: bring in the family. Genomics 85: 551-556, 2005.

175. Suzuki A, Mizuno K, Ino Y, Okada M, Kikkawa F, Mizutani S, and Tomoda Y. Effects of 17 beta-estradiol and progesterone on growth-factor-induced proliferation and migration in human female aortic smooth muscle cells in vitro. Cardiovasc Res 32: 516-523, 1996.

176. Tabas I. Consequences of cellular cholesterol accumulation: basic concepts and physiological implications. J Clin Invest 110: 905-911, 2002.

177. Thorp E, Li G, Seimon TA, Kuriakose G, Ron D, and Tabas I. Reduced apoptosis and plaque necrosis in advanced atherosclerotic lesions of Apoe-/- and Ldlr-/- mice lacking CHOP. Cell Metab 9: 474-481, 2009.

178. Ting SB, Caddy J, Hislop N, Wilanowski T, Auden A, Zhao LL, Ellis S, Kaur P, Uchida Y, Holleran WM, Elias PM, Cunningham JM, and Jane SM. A homolog of Drosophila grainy head is essential for epidermal integrity in mice. Science 308: 411-413, 2005.

179. Ting SB, Wilanowski T, Cerruti L, Zhao LL, Cunningham JM, and Jane SM. The identification and characterization of human Sister-of-Mammalian Grainyhead (SOM) expands the grainyhead-like family of developmental transcription factors. Biochem J 370: 953-962, 2003.

180. Tse K, Tse H, Sidney J, Sette A, and Ley K. T cells in atherosclerosis. Int Immunol 25: 615-622, 2013.

181. Tsiantoulas D, Diehl CJ, Witztum JL, and Binder CJ. B cells and humoral immunity in atherosclerosis. Circ Res 114: 1743-1756, 2014.

182. Tsukano H, Gotoh T, Endo M, Miyata K, Tazume H, Kadomatsu T, Yano M, Iwawaki T, Kohno K, Araki K, Mizuta H, and Oike Y. The endoplasmic reticulum stressC/EBP homologous protein pathway-mediated apoptosis in macrophages contributes to the instability of atherosclerotic plaques. Arterioscler Thromb Vasc Biol 30: 1925-1932, 2010.

183. Tupler R, Perini G, and Green MR. Expressing the human genome. Nature 409: 832-833, 2001.

184. Ueda K, Lu Q, Baur W, Aronovitz MJ, and Karas RH. Rapid estrogen receptor signaling mediates estrogeninduced inhibition of vascular smooth muscle cell proliferation. Arterioscler Thromb Vasc Biol 33: 1837-1843, 2013.

185. van Thienen JV, Fledderus JO, Dekker RJ, Rohlena J, van Ijzendoorn GA, Kootstra NA, Pannekoek H, and Horrevoets AJ. Shear stress sustains atheroprotective endothelial KLF2 expression more potently than statins through mRNA stabilization. Cardiovasc Res 72: 231-240, 2006.

186. Verhagen SN and Visseren FL. Perivascular adipose tissue as a cause of atherosclerosis. Atherosclerosis 214: 3-10, 2011.

187. Villablanca AC, Tenwolde A, Lee M, Huck M, Mumenthaler S, and Rutledge JC. 17beta-estradiol prevents early-stage atherosclerosis in estrogen receptor-alpha deficient female mice. J Cardiovasc Transl Res 2: 289-299, 2009.

188. Vinson C, Myakishev M, Acharya A, Mir AA, Moll JR, and Bonovich M. Classification of human B-ZIP proteins based on dimerization properties. Mol Cell Biol 22: 63216335, 2002.

189. Vinson CR, Sigler PB, and McKnight SL. Scissors-grip model for DNA recognition by a family of leucine zipper proteins. Science 246: 911-916, 1989.

190. Voglauer R, Chang MW, Dampier B, Wieser M, Baumann K, Sterovsky T, Schreiber M, Katinger H, and Grillari J. SNEV overexpression extends the life span of human endothelial cells. Exp Cell Res 312: 746-759, 2006.

191. Wang JC and Bennett M. Aging and atherosclerosis: mechanisms, functional consequences, and potential therapeutics for cellular senescence. Circ Res 111: 245-259, 2012.

192. Wang N, Miao H, Li YS, Zhang P, Haga JH, Hu Y, Young A, Yuan S, Nguyen P, Wu CC, and Chien S. Shear stress regulation of Krüppel-like factor 2 expression is flow pattern-specific. Biochem Biophys Res Commun 341: 1244-1251, 2006.

193. Wang W, Ha CH, Jhun BS, Wong C, Jain MK, and Jin ZG. Fluid shear stress stimulates phosphorylation-dependent nuclear export of HDAC5 and mediates expression of KLF2 and eNOS. Blood 115: 2971-2979, 2010.

194. Wani MA, Means RT, Jr., and Lingrel JB. Loss of LKLF function results in embryonic lethality in mice. Transgenic Res 7: 229-238, 1998.

195. Wanstall JC, Homer KL, and Doggrell SA. Evidence for, and importance of, cGMP-independent mechanisms with NO and NO donors on blood vessels and platelets. Curr Vasc Pharmacol 3: 41-53, 2005.

196. Wassmann K, Mueller CF, Becher UM, Werner C, Jung A, Zimmer S, Steinmetz M, Nickenig G, and Wassmann S. Interaction of Inhibitor of DNA binding 3 (Id3) with Gut-enriched Kruppel-like factor (GKLF) and p53 regulates proliferation of vascular smooth muscle cells. Mol Cell Biochem 333: 33-39, 2010.

197. Wei CL, Wu Q, Vega VB, Chiu KP, Ng P, Zhang T, Shahab A, Yong HC, Fu Y, Weng Z, Liu J, Zhao XD, Chew JL, Lee YL, Kuznetsov VA, Sung WK, Miller LD, Lim B, Liu ET, Yu Q, Ng HH, and Ruan Y. A global map of p53 transcription-factor binding sites in the human genome. Cell 124: 207-219, 2006.

198. Weidemann A and Johnson RS. Biology of HIF-1alpha. Cell Death Differ 15: 621-627, 2008.

199. Weih F, Gräbner R, Hu D, Beer M, and Habenicht AJ. Control of dichotomic innate and adaptive immune responses by artery tertiary lymphoid organs in atherosclerosis. Front Physiol 3: 226, 2012.

200. Whitmarsh AJ and Davis RJ. Regulation of transcription factor function by phosphorylation. Cell Mol Life Sci 57: 1172-1183, 2000.

201. Wilanowski T, Tuckfield A, Cerruti L, O'Connell S, Saint R, Parekh V, Tao J, Cunningham JM, and Jane SM. A highly conserved novel family of mammalian developmental transcription factors related to Drosophila grainyhead. Mech Dev 114: 37-50, 2002.

202. Wingender E, Schoeps T, Haubrock M, and Donitz J. TFClass: a classification of human transcription factors and their rodent orthologs. Nucleic Acids Res 43: D97-D102, 2015.

203. Wolfe SA, Nekludova L, and Pabo CO. DNA recognition by Cys2His2 zinc finger proteins. Annu Rev Biophys Biomol Struct 29: 183-212, 2000. 
204. Wu W, Xiao H, Laguna-Fernandez A, Villarreal G, Jr., Wang KC, Geary GG, Zhang Y, Wang WC, Huang HD, Zhou J, Li YS, Chien S, Garcia-Cardena G, and Shyy JY. Flow-dependent regulation of krüppel-like factor 2 is mediated by microRNA-92a. Circulation 124: 633-641, 2011.

205. Xiao W. Advances in NF-kappaB signaling transduction and transcription. Cell Mol Immunol 1: 425-435, 2004.

206. Xing D, Miller A, Novak L, Rocha R, Chen YF, and Oparil S. Estradiol and progestins differentially modulate leukocyte infiltration after vascular injury. Circulation 109: 234-241, 2004.

207. Yamamoto K, Protack CD, Kuwahara G, Tsuneki M, Hashimoto T, Hall MR, Assi R, Brownson KE, Foster TR, Bai H, Wang M, Madri JA, and Dardik A. Disturbed shear stress reduces Klf 2 expression in arterial-venous fistulae in vivo. Physiol Rep 3: e12348, 2015.

208. Yao S, Miao C, Tian H, Sang H, Yang N, Jiao P, Han J, Zong $\mathrm{C}$, and Qin S. Endoplasmic reticulum stress promotes macrophage-derived foam cell formation by upregulating cluster of differentiation 36 (CD36) expression. J Biol Chem 289: 4032-4042, 2014.

209. Yao S, Sang H, Song G, Yang N, Liu Q, Zhang Y, Jiao P, Zong $\mathrm{C}$, and Qin S. Quercetin protects macrophages from oxidized low-density lipoprotein-induced apoptosis by inhibiting the endoplasmic reticulum stress-C/EBP homologous protein pathway. Exp Biol Med (Maywood) 237: 822-831, 2012.

210. Yao S, Zong C, Zhang Y, Sang H, Yang M, Jiao P, Fang Y, Yang N, Song G, and Qin S. Activating transcription factor 6 mediates oxidized LDL-induced cholesterol accumulation and apoptosis in macrophages by up-regulating $\mathrm{CHOP}$ expression. J Atheroscler Thromb 20: 94-107, 2013.

211. Yokota Y and Mori S. Role of Id family proteins in growth control. J Cell Physiol 190: 21-28, 2002.

212. Zeller KI, Zhao X, Lee CW, Chiu KP, Yao F, Yustein JT, Ooi HS, Orlov YL, Shahab A, Yong HC, Fu Y, Weng Z, Kuznetsov VA, Sung WK, Ruan Y, Dang CV, and Wei CL. Global mapping of c-Myc binding sites and target gene networks in human B cells. Proc Natl Acad Sci U S A 103: 17834-17839, 2006.

213. Zhou G, Hamik A, Nayak L, Tian H, Shi H, Lu Y, Sharma N, Liao X, Hale A, Boerboom L, Feaver RE, Gao H, Desai A, Schmaier A, Gerson SL, Wang Y, Atkins GB, Blackman BR, Simon DI, and Jain MK. Endothelial Krüppel-like factor 4 protects against atherothrombosis in mice. J Clin Invest 122: 4727-4731, 2012.

214. Zhou J, Lhotak S, Hilditch BA, and Austin RC. Activation of the unfolded protein response occurs at all stages of atherosclerotic lesion development in apolipoprotein Edeficient mice. Circulation 111: 1814-1821, 2005.

Address for correspondence: Dr. Joachim Altschmied IUF-Leibniz, Research Institute for Environmental Medicine Auf'm Hennekamp 50 Düsseldorf 40225 Germany

E-mail: joachim.altschmied@uni-duesseldorf.de
Date of first submission to ARS Central, November 9, 2016; date of acceptance, November 11, 2016.

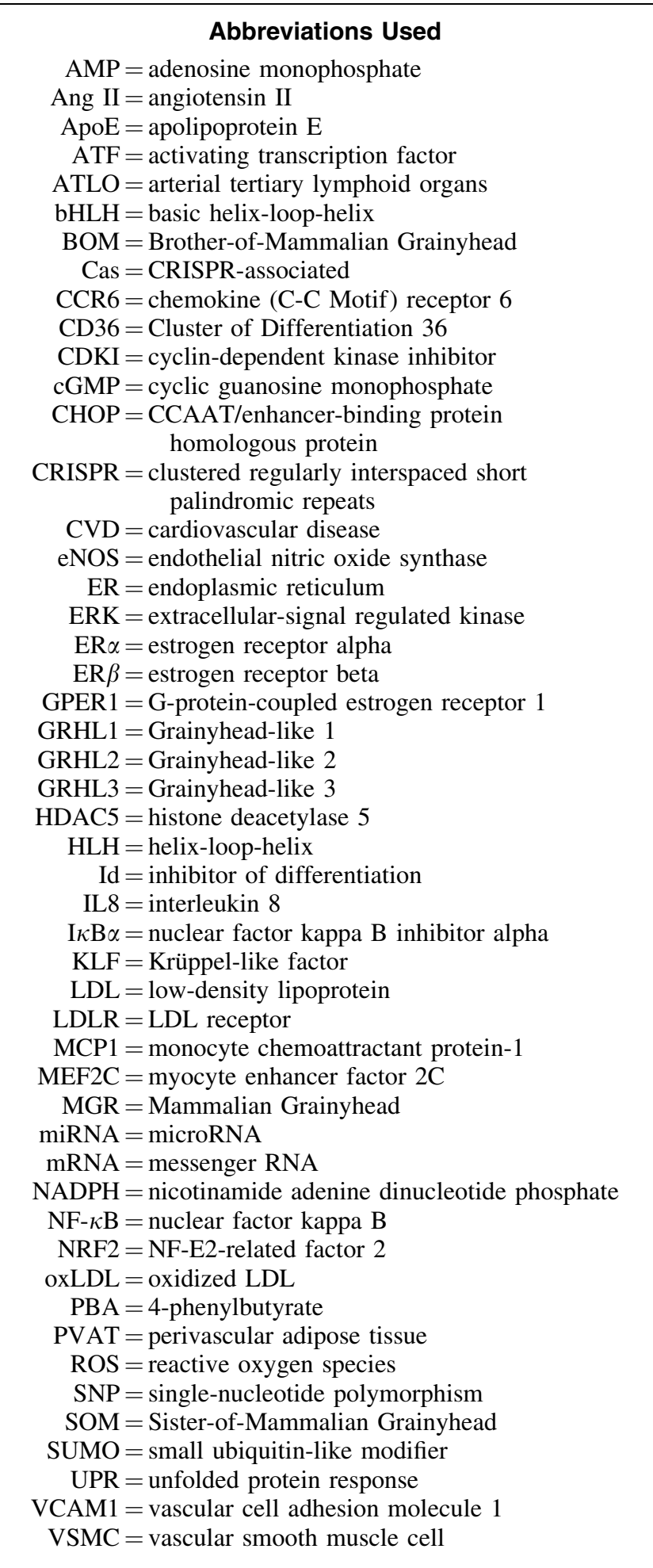

